USEPA مقايسه روشهاى درونيابى بهمنظور بهنهبندى ميزان فرسايش بادى با مدل

اسماعيل مرادى و داود نامدار خجسته ا"*

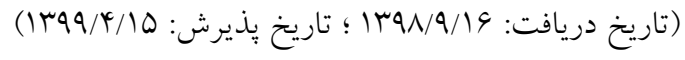

جكيده

فرسايش بادى يكى از مشكلات زيستمحيطى در كشور بهخصوص در مناطق خشك و نيمهخشى كشور اسـت. طسى سـاليان اخيسر روشهـا و

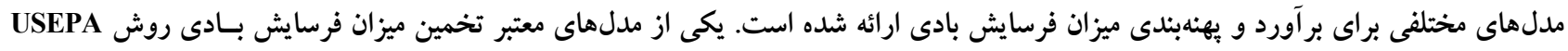

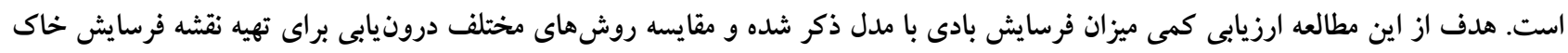

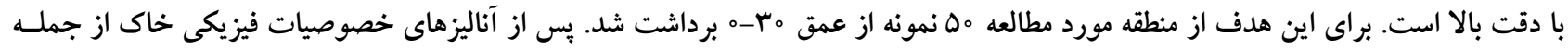

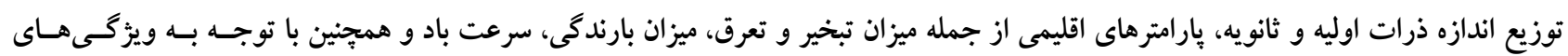

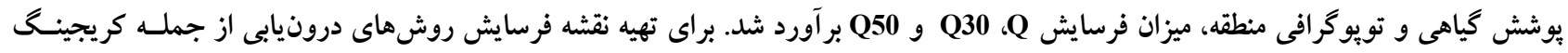

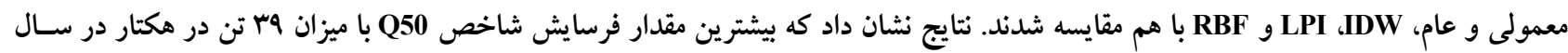

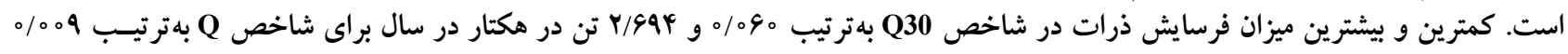

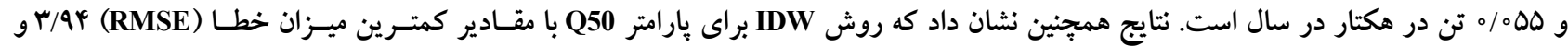

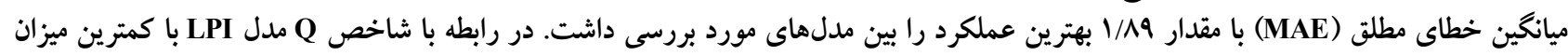

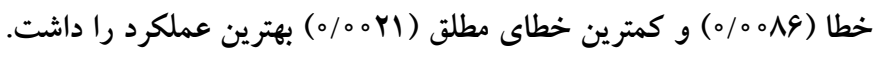

وازههاى كليدى: براكنش مكانى، كريجينگ، درونيابى، فرسايش بادى

1. كروه علوم و مهندسى خاك، دانشكده كشاورزى، دانشگاه شاهد، تهران، ايران.

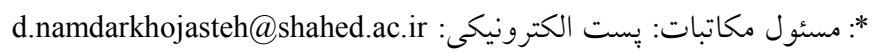


روش USEPA است. روش USEPA يكى از روشهاى جديد

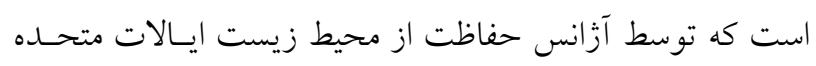

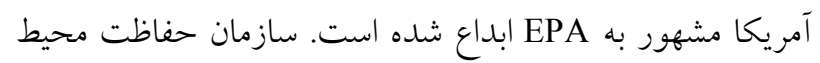

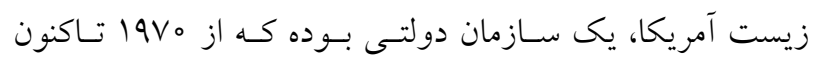

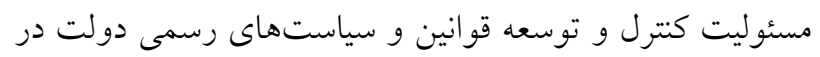

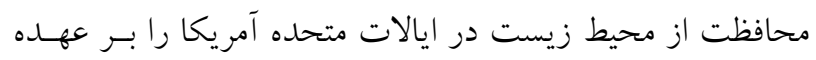
داشته است.

علاوه بـر تعيـين كمـى ميـزان فرسـايش، آكَاهى از ميـزان

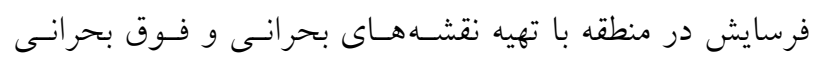

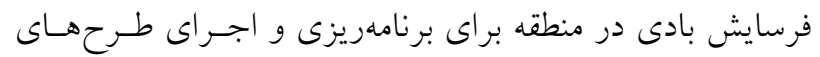

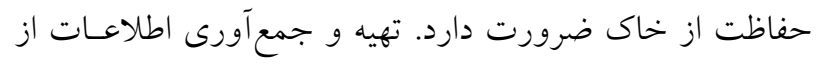

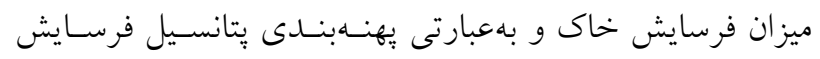

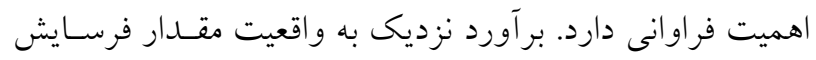
و رسـوب در يـك منطقـه موضـوع مهمسى اسـت كـه همـو اره

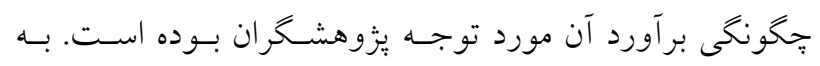
منظور بسط و كسترش اطلاعات ميزان فرسايش بهدسـت آمــــه

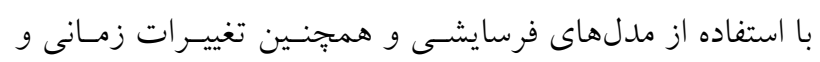

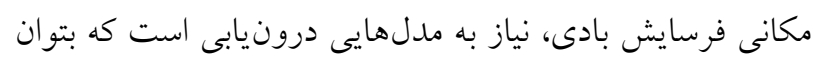

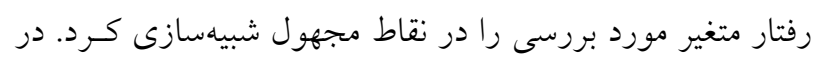

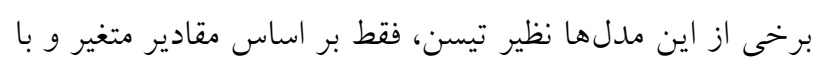

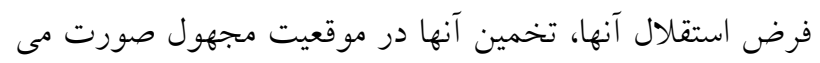

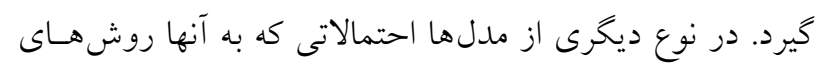

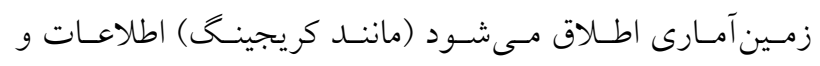

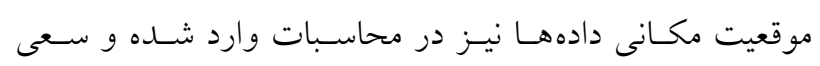

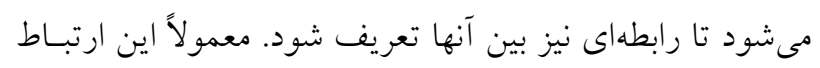

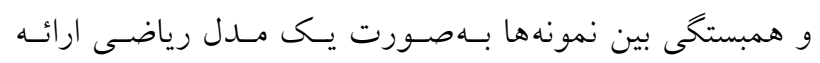

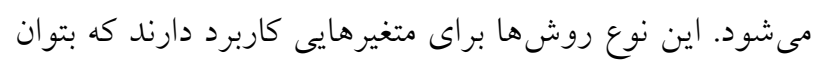

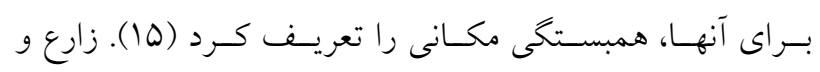

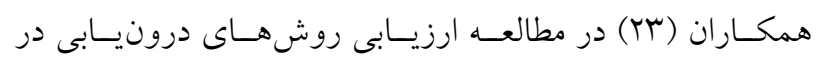

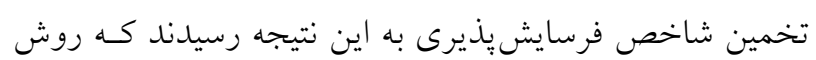

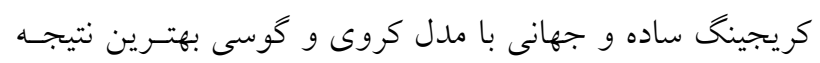

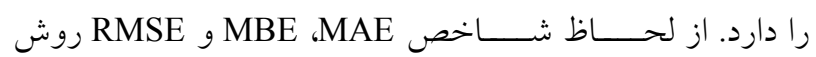

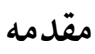

فرسايش يكى از مهمترين مشكلات تخريب در اكوسيستمهـاى

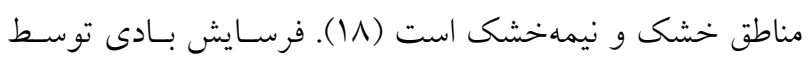

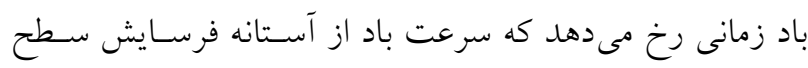

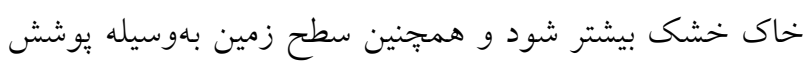

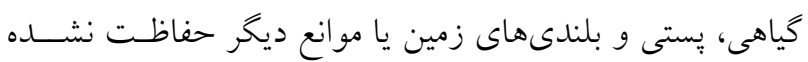

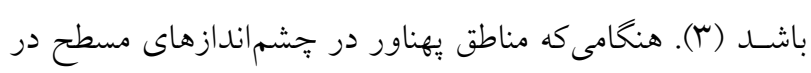

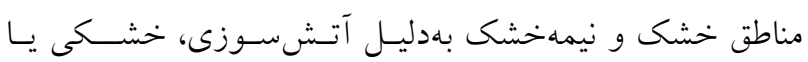

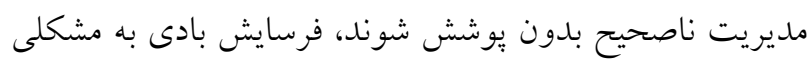

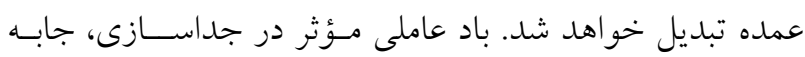

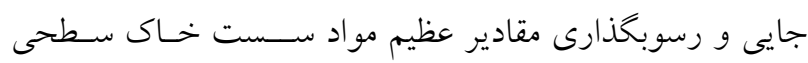

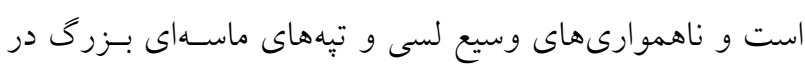

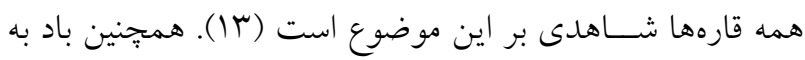

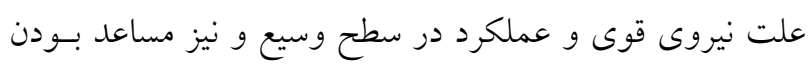

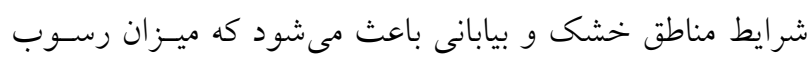

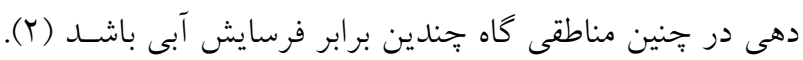

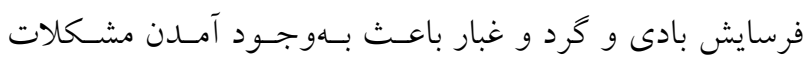

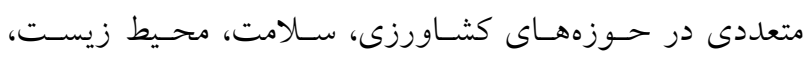
صنعت و غيـره مسى شـوند (IV). بـراى تهيـه داده كمسى ميـزان

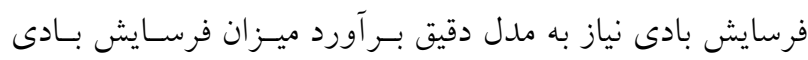

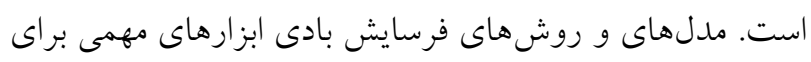

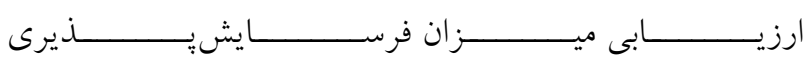
خاى، شناسايى شيوههاى مديريت براى كنترل فرسايش و خـرد

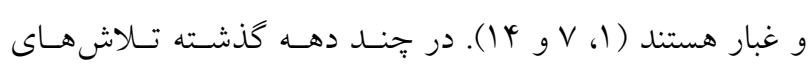

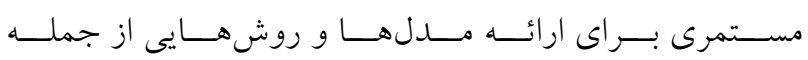

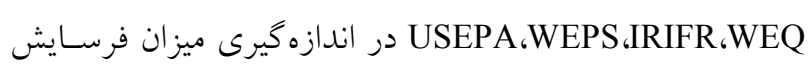
بادى و منشأ يابى گرد و غبار در اراضى كشاورزى انجام گرفتسه

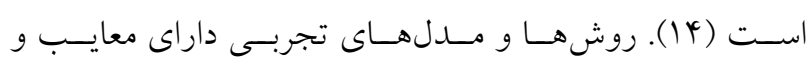

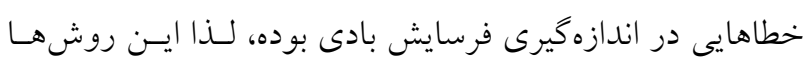

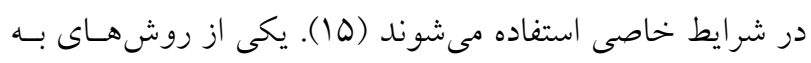
نسبت جديدى كه براى اندازهيرى ميزان فرسايش بادى و منشأ

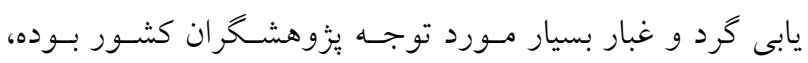


كشاورزى، اراضى تاغكارى شده، شورهزارهايى با بوشـش كـم،

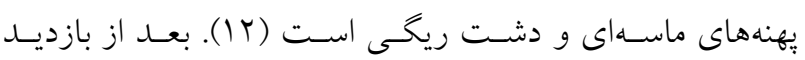
ميدانى از منطقه مورد مطالعه و مطالعات مقدماتى، نمونهبردارى

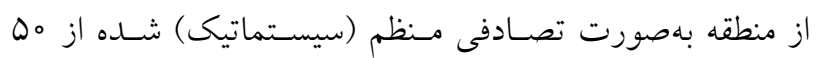
نقطه از سطح منطقه مورد مطالعه (جنوب روسـتاى دلازيـان در

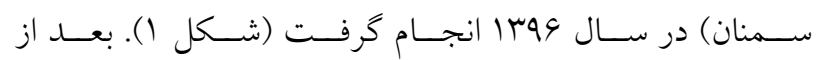
نمونهبردارى، آزمايشهاى توزيـع انــازه ذرات، بافـت خـاك و شورى روى نمونهها انجام كرفت.

آزمايشهاى بافت و توزيع اندازه ذرات اندازه كيرى بافت خاى بهروش هيدرومتر (ه) براى اندازهخيـرى ميانخين قطر ذرات (MWD) از دستخاه الك خشك استفاده شد.

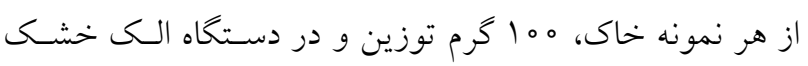

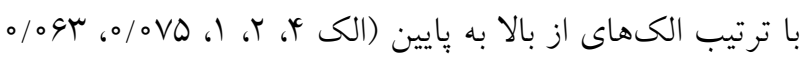

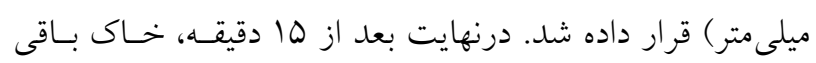
مانده روى الكها توزين شدند (11).

\section{تهيه دادهاى هواشناسى و اقليمى}

دادههاى اقليمى از جمله تبخير، سرعت باد، بارنـدكى و دمـا در

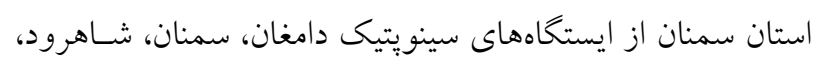

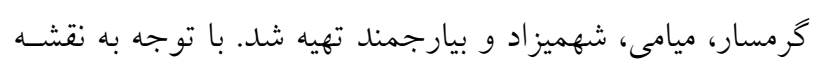
تيسن تهيه شده براى كل استان (شكل Y)، منطقه مـورد مطالعـه در محدوده ايستخاه سمنان قرار گرفـت و از دادههـاى ايستخاه سينويتيك سمنان براى ارزيابى مدل استفاده شد.

اندازهيرى و محاسبه گرد و غبار با استفاده از روش سازمان حفاظت محيط زيست آمريكا (USEPA) در سالهاى اخير اندازهذيرى ميزان هدررفت خاك با استفاده از

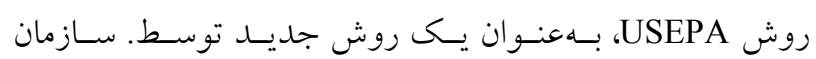
حفاظت محيط زيست آمريكا ارائه شده است. در ايسن روش بـا

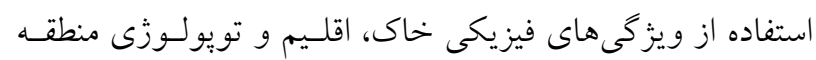

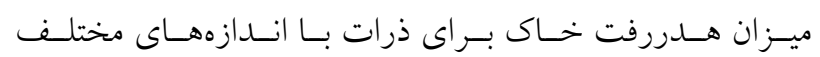

كريجينگ معمولى داراى صحت بيشتر و خطاى كمتـرى اسـت.

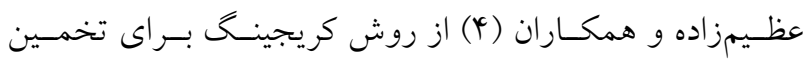
درصد سنگفرش بيابانى و سرعت آستانه فرسايش بادى اسـتفاده كردند. نتايج محققين نشان داد كـه اسـتفاده از روش كريجينـ معمولى شيوه مناسب و دقيق براى تهيه نقشه اسـت. صـارمى و همكاران (9 (1) در تحقيقى با بهـنهبنـدى مقـادير سـرعت آسـتانه

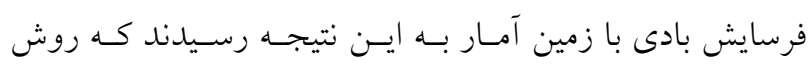
كريجينخ نسبت به IDW روش مناسبتـرى اسـت. واعظى و

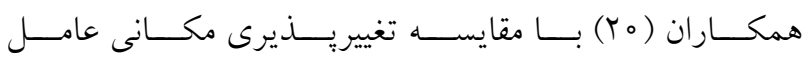
فرسايش يذيرى خاك برآورد شده و اندازهيـرى شــده در مــدل

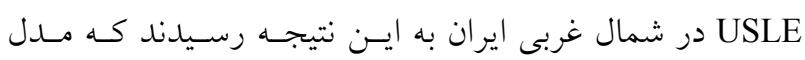
نمايى مناسبترين مدل براى تغييرات مكـانى فرسـايش يـذيرى

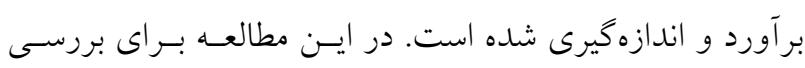

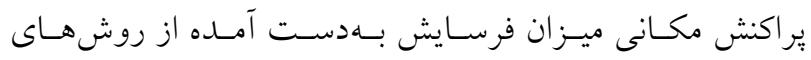
درونيابى زمين آمارى و غير زمين آمارى با توجه به آنـاليز اوليـه آمارى دادهها با هم مقايسه شدند. با توجه به مطالب كفته شـده، رئه

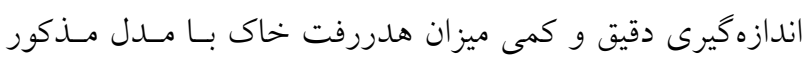

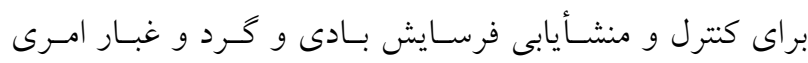
ضرورى است. هدف از اين يـزَوهش ارزيـابى ميـزان فرسـايش بادى در منطقه با مدل USEPA و تهيه نقشه ميزان فرسـايش بـا مدلهاى زمين آمارى و منطقى است.

\section{مواد و روشها} مشخصات كلى منطقه مورد مطالعه

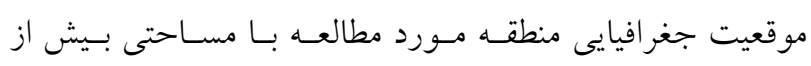

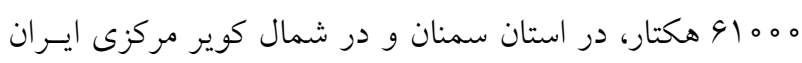
(دشت كوير) و جنوب روستاى دلازيان قرار دارد. اقلسيم منطقـه با استفاده از روش آميرزه جزء مناطق اقليم خشك و وردي سرد است. در قسمت عمده كوير بوشـش كيـاهى بسـيار ضـعيف و بيشـتر

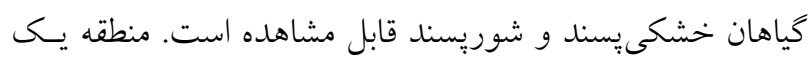
دست، داراى تبه هاى فرسايش يافته در جاهايى از منطقه تلماسه

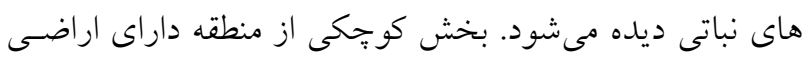


- Sample Points
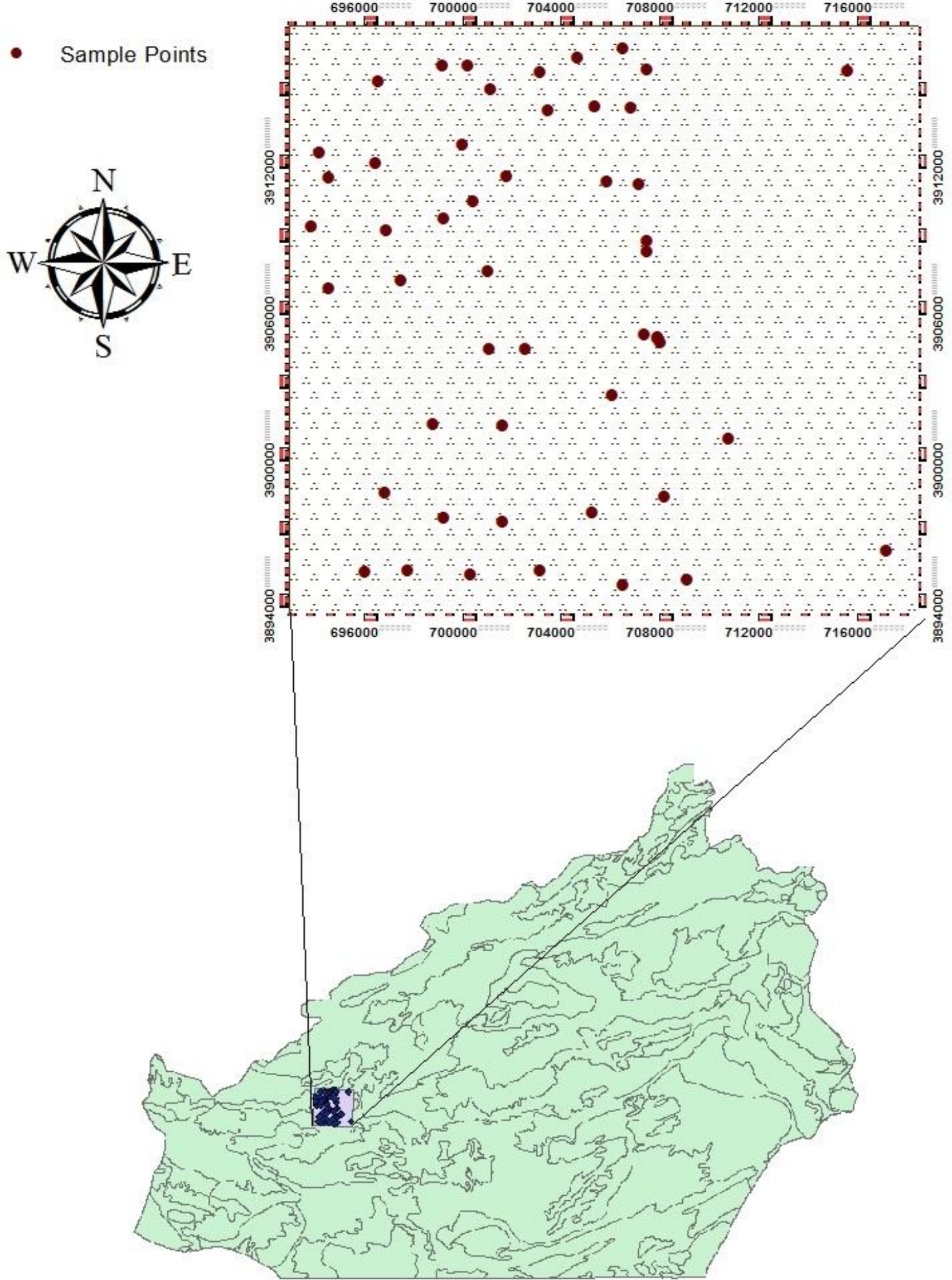

Semnan Province, Iran

شكل ا. نقشه منطقه مورد مطالعه در استان سمنان 


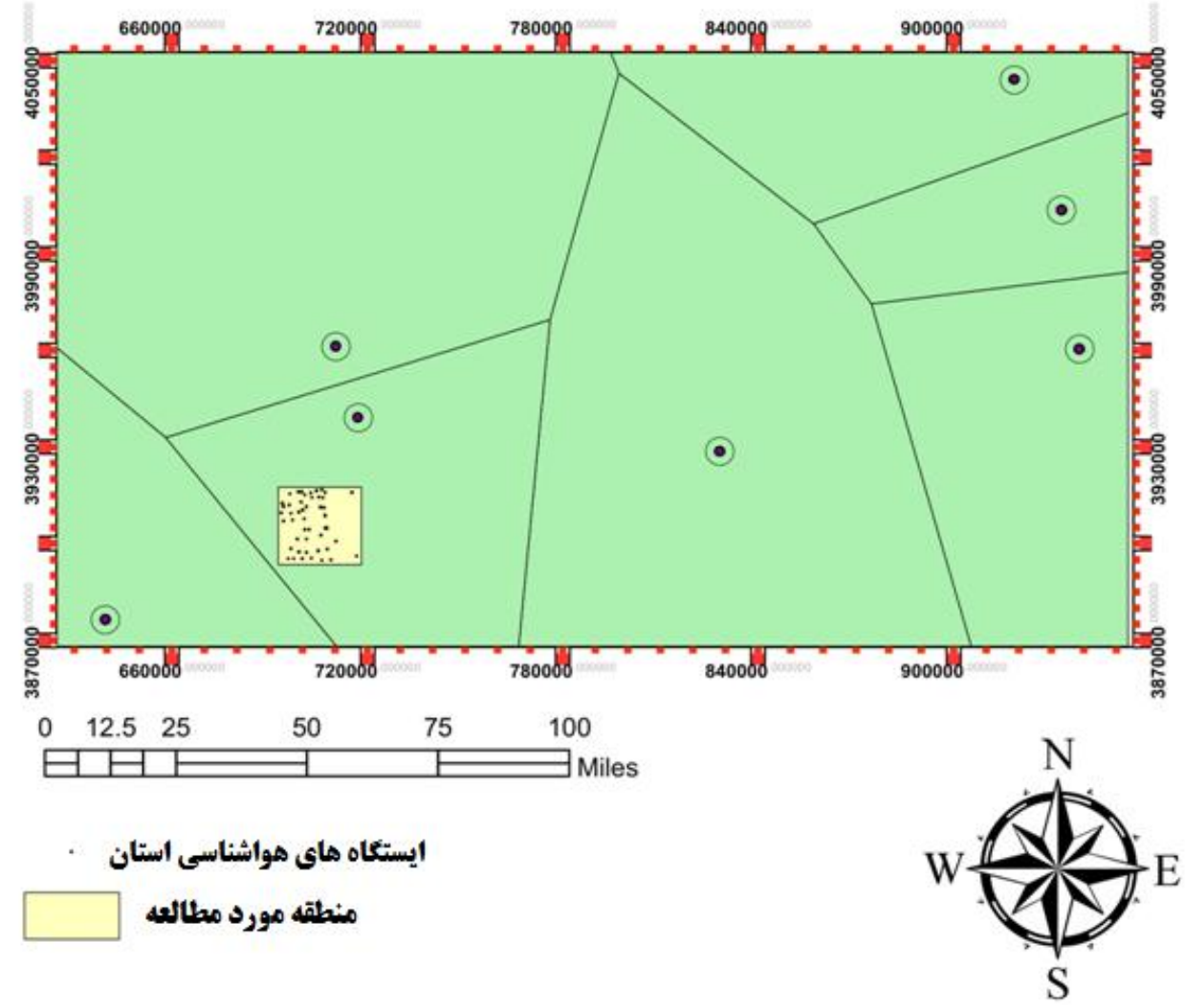

شكل r. موقعيت جغرافيايى ايستخاهها در استان سمنان

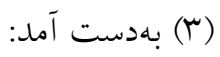

$\mathrm{PE}=300 \frac{\mathrm{P}}{\mathrm{E}}$

كه در آن: P Pيانخين بارند تبخير از تشتك سالانه است.

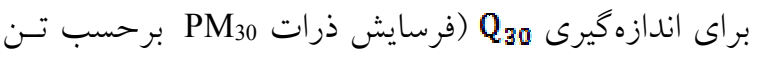

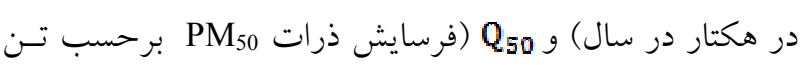
در هكتار در سال) از معادلات با و ه ه استفاده شد:

$\mathrm{Q}_{30}=0.2058 \mathrm{ec}_{75} \mathrm{fPE}^{-2}$

$\mathrm{Q}_{50}=\mathrm{ec}_{50} \mathrm{KCLVA}$

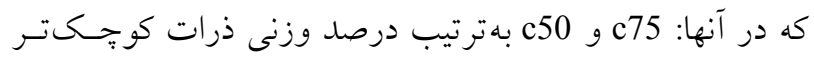

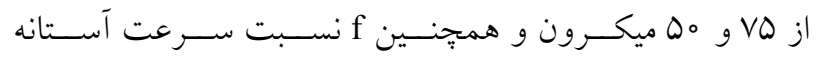

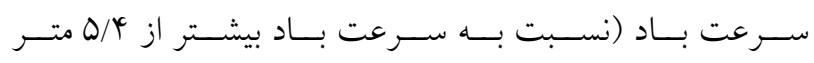

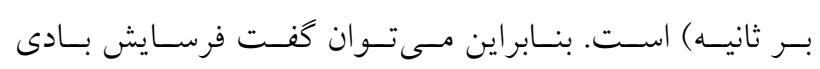

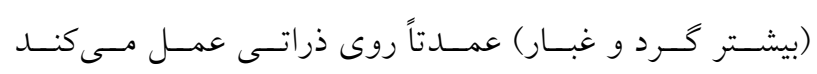

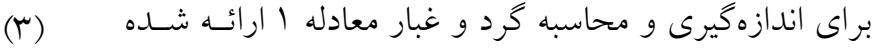

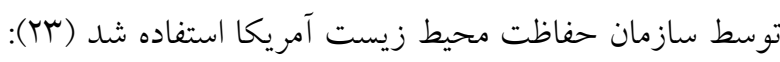
$\mathrm{Q}=\mathrm{ceKCLVA}$ كه در آن: Q مقدار فرسايش در سطح A هكتار (برحسب تن بر

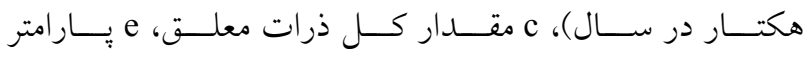
فرسايش يذيرى خاك (اطلاعات بيشتر در مـورد نحسوه محاسـبه يارامترهاى c و e در مطالعات زان (YY) ارائسه شـده اسـت). نشاندهندة ضريب يوشش كياهى و L عامل عرض، K ضـريب

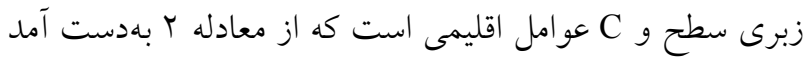

$\mathrm{C}=\frac{0.504 \mathrm{U}^{3}}{\mathrm{PE}^{2}}$

كه در آن: Uيانخين سرعت سالانه باد (برحسب متر بر ثانيـه)،

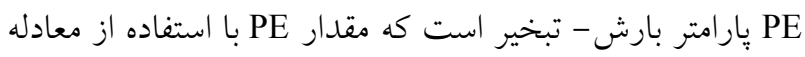


نقاط با يكـديخر بـوده و در خـارج ايـن فاصـله رفتـار نقـاط

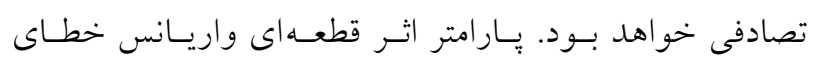

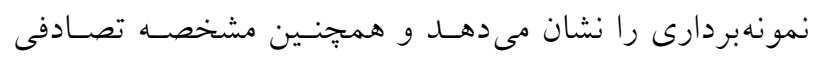

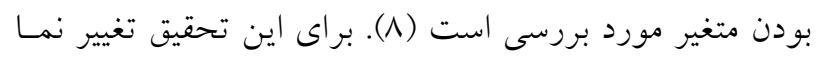

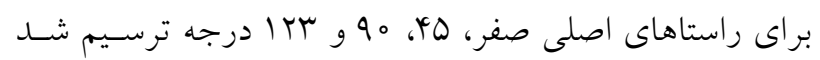

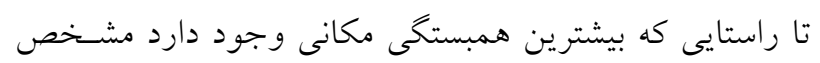

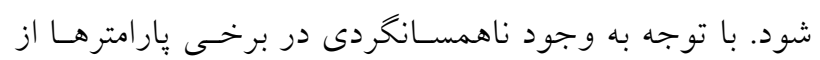

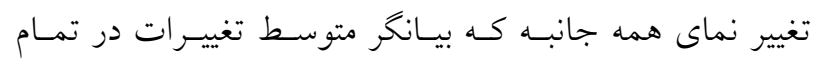

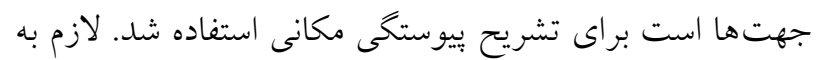

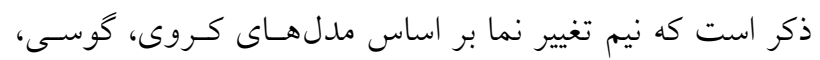

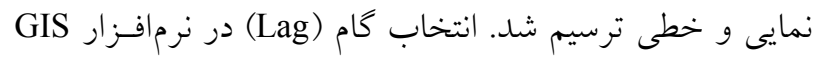

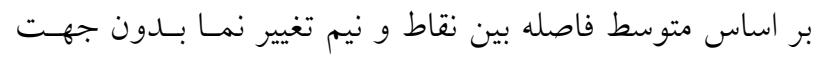

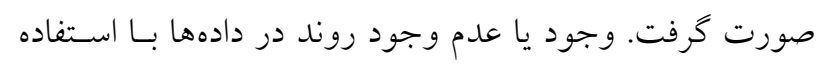

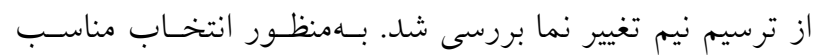

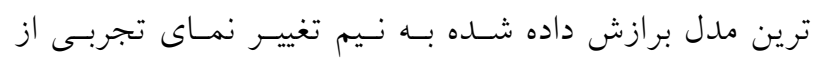
اعتبارسنجى متقاطع استفاده شد. مدلى كه دارى خطاى كمتسر،

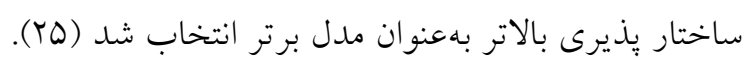

انتخاب روشهاى درونيابى براى ترسيم نقشه

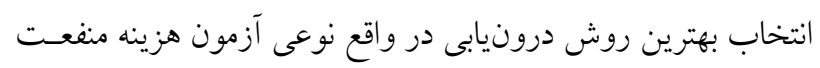

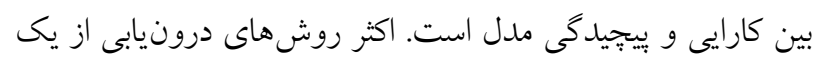

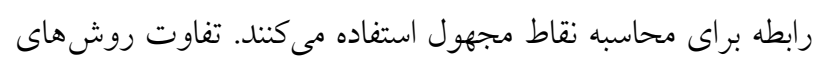
مختلف درونيابى، در وزن اختصاص داده شده به هر نقطـه اسـت.

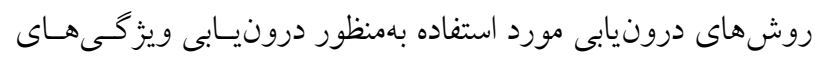

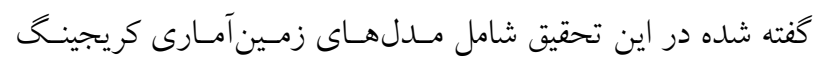

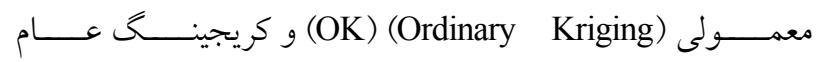
و مدلهاى قطعى شـامل روش تـابع (UK) (Universal Kriging)

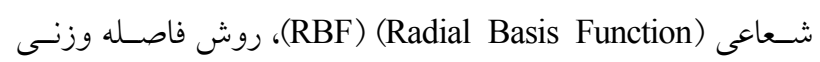

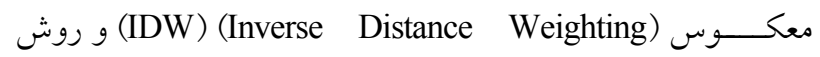
جندجملـاى محلى (LPI) (Local Polynomial Interpolation)

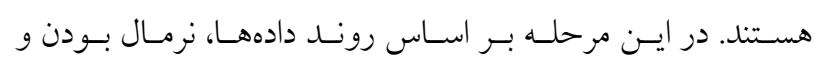

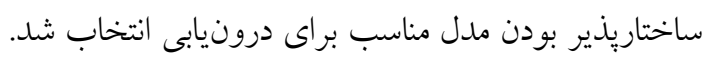

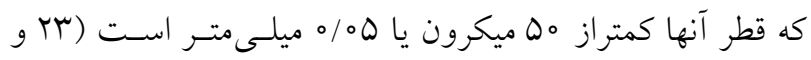

\section{بررسى توزيع، همبستخى و رگرسيون متغيرها} قبل از انتخاب روش مناسب براى دروني برونيابى دادها، ابتدا تجربهو

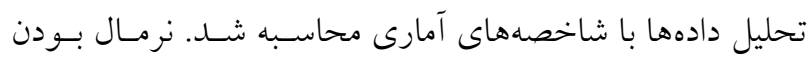

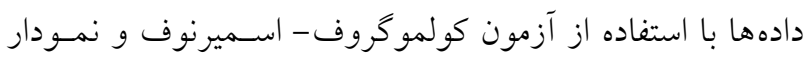

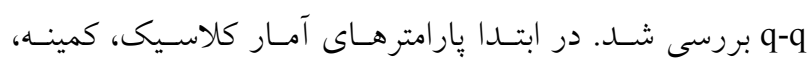

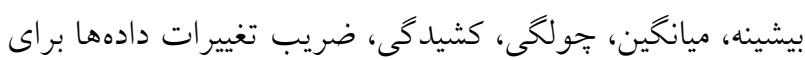

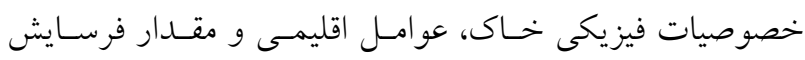

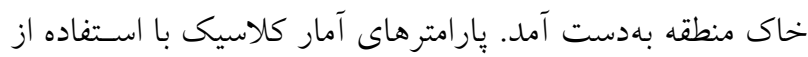

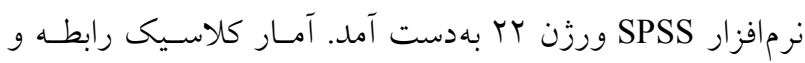

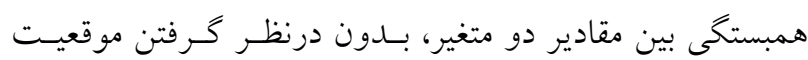

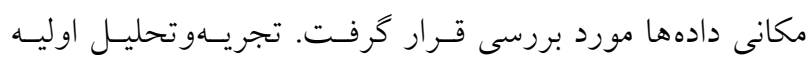

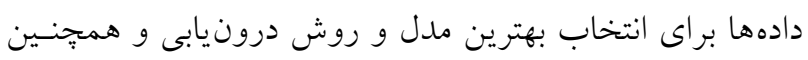
تهيه نقشه كاربرد زيادى دارد.

نيم تغييرنما

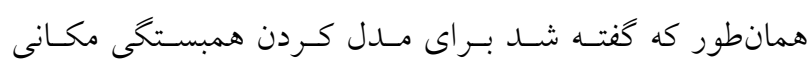

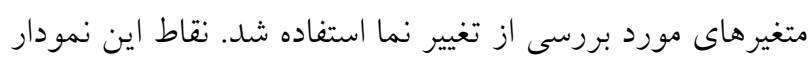

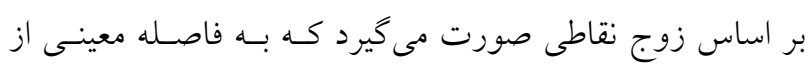

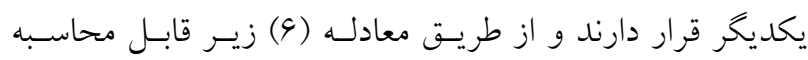

$\gamma(\mathrm{h})=\frac{1}{2(\mathrm{~N}-\mathrm{h})} \sum_{\mathrm{i}=1}^{\mathrm{n}-\mathrm{h}}[z(\mathrm{x}+\mathrm{h})-\mathrm{z}(\mathrm{x})]^{2}$

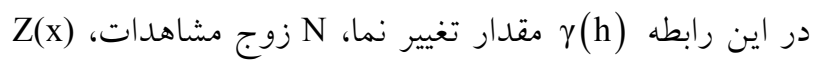

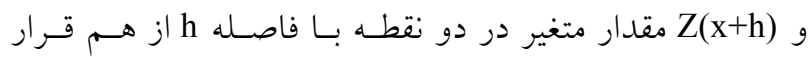

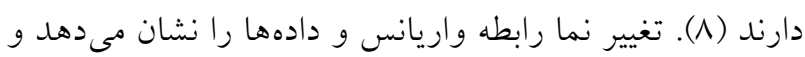

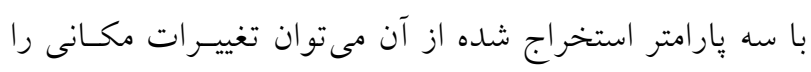

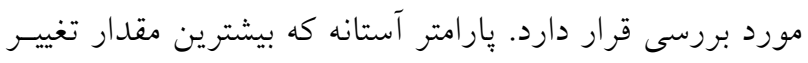

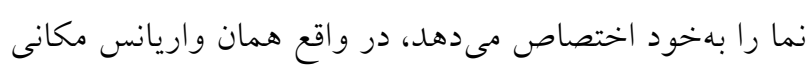

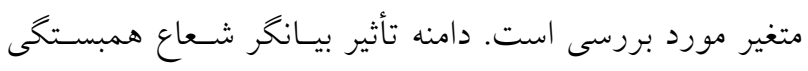


$\sum_{\mathrm{i}=1}^{\mathrm{n}} \mathrm{W}_{\mathrm{i}}\left[\mathrm{F}\left(\mathrm{x}_{\mathrm{i}}, \mathrm{y}_{\mathrm{i}}\right)-\mathrm{Z}_{\mathrm{i}}\right]^{2}=$ Minimize

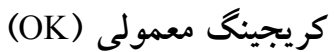

اين روش تخمين گرى است كه مقادير يك متغيـر رادر نقــاط نمونهبردارى نشده بهصورت تركيـب خطى از مقـادير همـان

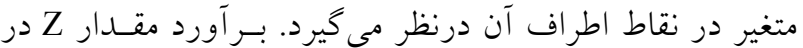
نقطه x0 بهوسيلة اين روش به صورت معادله 9 بيان مى شودد: $\mathrm{Z}_{\mathrm{OK}}^{*}\left(\mathrm{x}_{0}\right)=\sum_{\mathrm{i}=1}^{\mathrm{n}} \lambda_{\mathrm{i}} \mathrm{Z}\left(\mathrm{x}_{\mathrm{i}}\right)$

كه در اين معادله

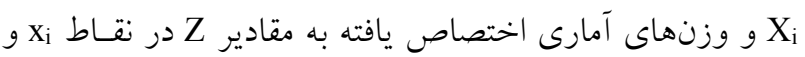

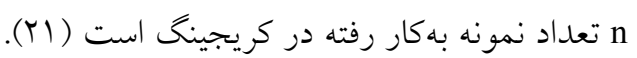

\section{كريجينگ عام (Universal Kriging)}

در كريجينگ ساده مقدار ميانخين متغيرها در منطقه ثابت فـرض مىشود. در بعضى حالتهاى كاربردى، ميانخين محلى در منطقه مورد مطالعه متغير است. كريجينگ عام دربر گيرنده حالتهـايى

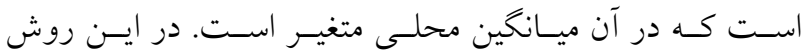

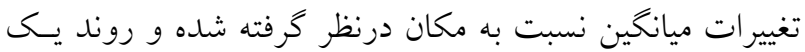

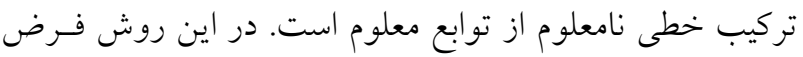

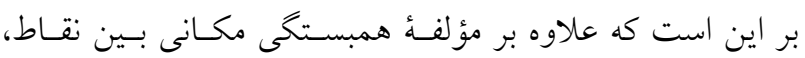
انحراف يا روند نيز در مقادير z وجـود دارد. در ايـن صـورت،

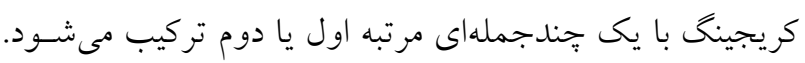

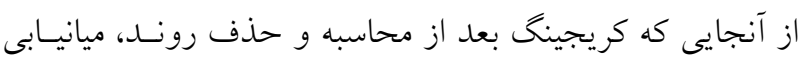

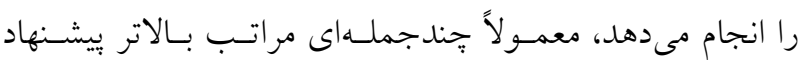
نمى شود. لذا جندجملهاى مراتب بـالاتر تغييـرات محسدودى را

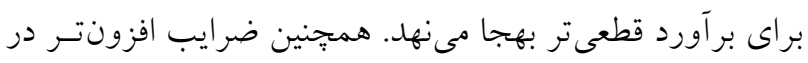

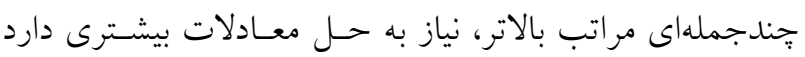

$\mu_{\mathrm{x}}=\sum_{\mathrm{i}=1}^{\mathrm{n}} \mathrm{a}_{\mathrm{i}} \mathrm{f}_{\mathrm{i}}(\mathrm{x})$

در معادله ما براى درونيـابى، a ام ضـريب تخمسين زده شــهـ
روش فاصله وزنى معكوس (IDW)

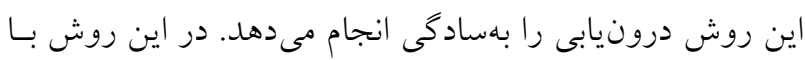

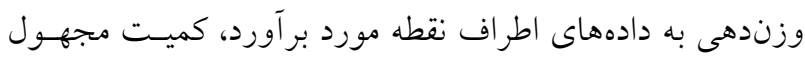

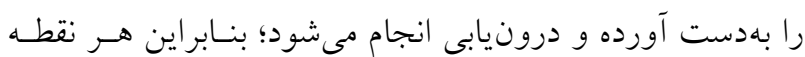
اندازهيرى شده داراى يك اثر محلى است و با افزايش فاصـله،

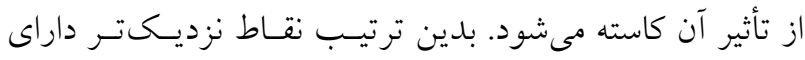

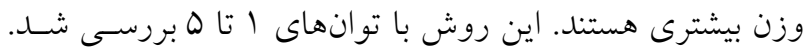
در اين روش فاصـله هـر نقطـه يـا ييكسـل بـا ييكسـل مجـاور

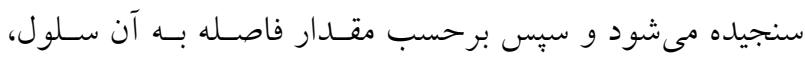
ارزش يا ضـريب وزن داده مسىــود و درنهايـت ارزش سـلول

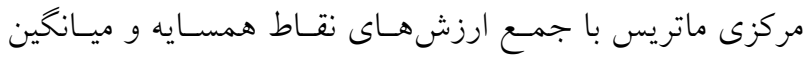

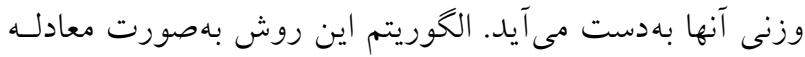

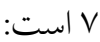
$\lambda_{i}=\frac{\frac{1}{d_{i}^{p}}}{\sum_{i=1}^{n} \frac{1}{d_{i}^{p}}} Z^{*}=\sum_{i=1}^{n} \lambda_{i} Z\left(x_{i}\right)$

در اين معادله Z مقدار نقطه مجهـول، Z(X) مقـدار مربـوط بـهـ نقطه i ام، n تعداد نقاط نمونهبردارى است. در ايسن مطالعهـ بـهـ

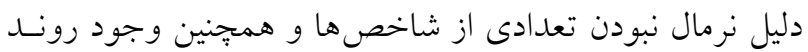

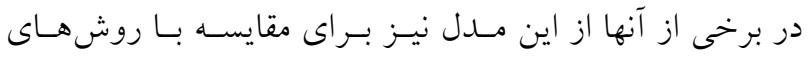

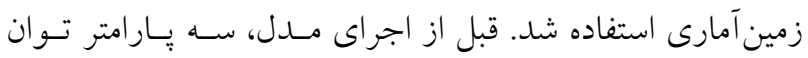

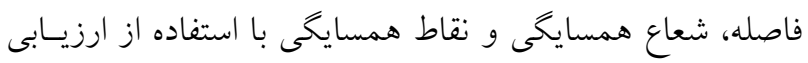

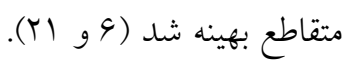

\section{روش جندجملهاى محلى (LPI)} اين روش حداقل مجذورات متناسب را بين كرههاى شناسـيى لئ شده در محدوده بيضوى شكل، بـهنسوان وزن گـره تخصسيص

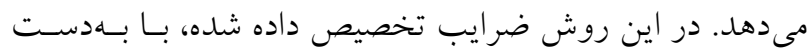

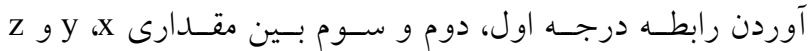
حداقل سازى اطلاعات محاسبه شده، مطابق معادله 1 درونيـابى صورت مى گيرد. 
ST $: \psi(d)=\ln (\mathrm{cd} / 2)^{2}+\mathrm{I}_{0}(\mathrm{~cd})+\gamma$

TPS : $\psi(d)=c^{2} d^{2} \ln (c d)$

در اين معادلات d فاصله بين نقاط نمونسهبــردارى و يسيشبينس

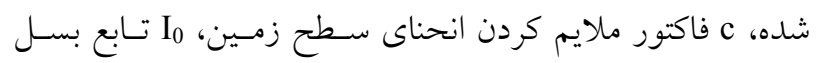
اصلاح شده و

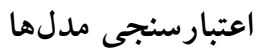
بهمنظور مقايسـه روش هـاى مـورد اسـتفاده در ايـن يـزّوهش و

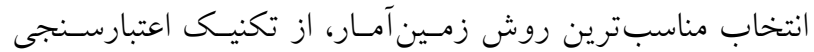
متقابل استفاده شـــ. در ايـن روش، در هـــ مرحلـه يـك نقطـه

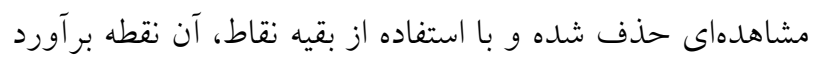
مىشود. اين كار براى همه نقاط مشاهدهاى تكرار مسىشـود، بـهـ

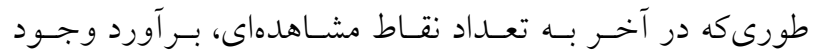

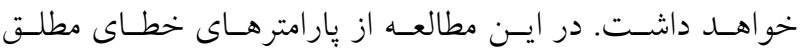
ميـانخين (MAE) و مجـذور ميـانخين مربعـات خطـا (RMSE)

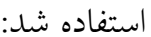

$$
\text { RMSE }=\sqrt{\frac{\sum_{\mathrm{i}=1}^{\mathrm{n}}\left[\overline{\mathrm{Z}}\left(\mathrm{x}_{\mathrm{i}}\right)-\mathrm{Z}\left(\mathrm{x}_{\mathrm{i}}\right)\right]^{2}}{\mathrm{~N}}}
$$

$$
\mathrm{MAE}=\frac{\sum_{i=1}^{n}\left|\mathrm{Z}\left(\mathrm{x}_{\mathrm{i}}\right)-\overline{\mathrm{Z}}\left(\mathrm{x}_{\mathrm{i}}\right)\right|}{\mathrm{N}}
$$

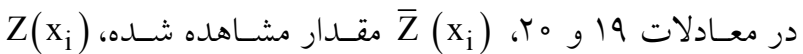

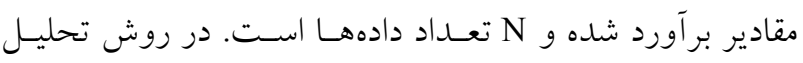
رخرسيونى، بين دادههاى واقعى و دادههاى برآوردى يكى رابطه.

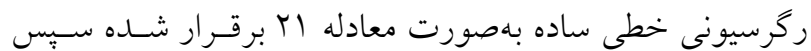
اين معادله با خط ا: ا: مقايسه مىشود (YI). $\mathrm{Y}=\mathrm{a}+\mathrm{bX}$

بهعبارتى هرجهه عرض از مبدأ (a) به صـفر و شـيب (b) بـهـ

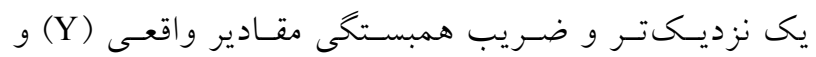

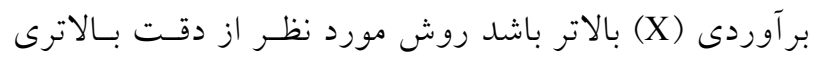

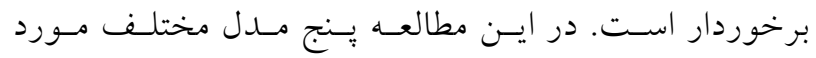

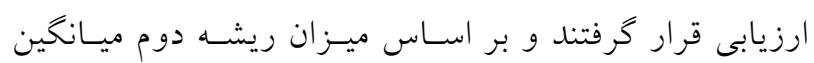

توسط دادهها، i ام تابع توزيع مكـانى، n i تعـداد تـابع اسـتفاده شده در مدلسازى است.

روش تابع شعاعى (RBF) اين روش مىتواند روى دادههايى كه بـهـــور نـامنظم در يـــ

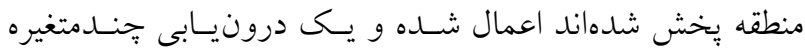

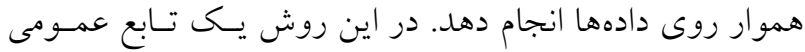
وابسته به فاصله بين نقاط درونيابى شده و نمونهبردارى شده به كار گرفته مىشود. تعريف رياضى اين روش در معادله 11 ارائه

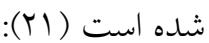

$\mathrm{Z}(\mathrm{x})=\sum_{\mathrm{i}=1}^{\mathrm{m}} \mathrm{a}_{\mathrm{i}} \mathrm{f}_{\mathrm{i}}(\mathrm{x})+\sum_{\mathrm{j}=1}^{\mathrm{n}} \mathrm{b}_{\mathrm{j}} \psi\left(\mathrm{d}_{\mathrm{j}}\right)$

در اين معادله نمونهبردارى و ييشبينى شده نقطه x را نشان مى دهد. در معادله

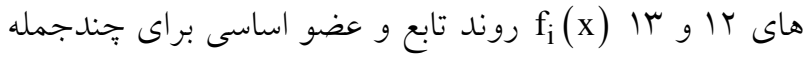
اىهاى با درجه كمتر از m است. در اين روش ضـرايب a

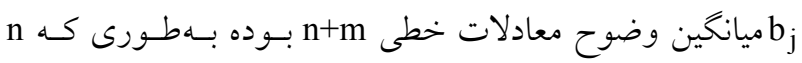
تعداد نقاط استفاده شده در درونيابى است. $\mathrm{Z}\left(\mathrm{x}_{\mathrm{k}}\right)=\sum_{\mathrm{i}=1}^{\mathrm{m}} \mathrm{a}_{\mathrm{i}} \mathrm{f}_{\mathrm{i}}\left(\mathrm{x}_{\mathrm{k}}\right)+\sum_{\mathrm{j}=1}^{\mathrm{n}} \mathrm{b}_{\mathrm{j}} \psi\left(\mathrm{d}_{\mathrm{jk}}\right) \quad$ for $\mathrm{k}=1,2, \ldots \ldots, \mathrm{n}$

$\sum_{j=1}^{n} b_{j} f_{k}\left(x_{j}\right)=0 \quad$ for $k=1,2, \ldots ., m$

روش تابع شعاعى خـود برحسـب نـوع تـابع، داراى يــنج نـوع اسبيلاين كاملاً منظم (CRS)، اسيّلاين كششى (ST)، استبيلاين خنــد ربعس (MQ)، اسـييلاين خنـــ ربعسى معكسوس (IMQ)، اسييلاين صفحهاى نازى (TPS) است كه هر يكى از آنها معادلـه

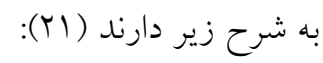

CRS : $\psi(\mathrm{d})=\ln (\mathrm{cd} / 2)^{2}+\mathrm{E}_{1}(\mathrm{~cd})^{2}+\gamma$

IMQ : $\psi(d)=\left(\sqrt{d^{2}+c^{2}}\right)^{-1}$

MQ : $\psi(d)=\sqrt{d^{2}+c^{2}}$ 
طريق آزمونهاى شايِيرو - ويلـك و آزمـون كولمـوكروف-

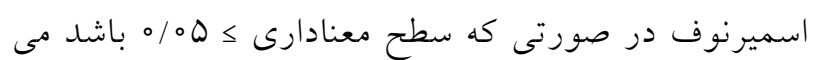

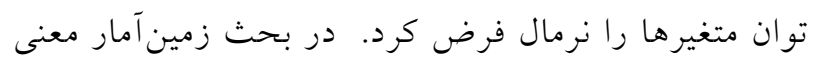

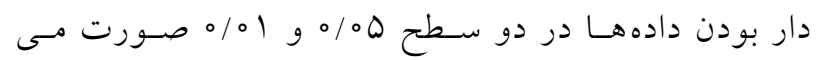
كيرد. همانطور كه در جدول r مشاهده مى شود نتايج ايسن

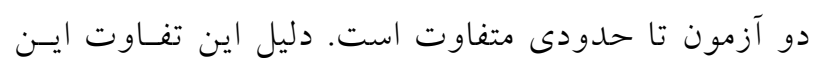

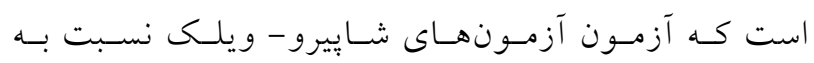

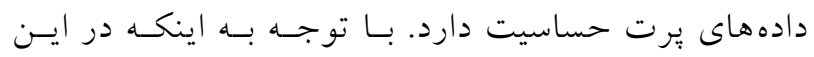

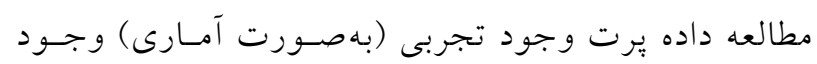

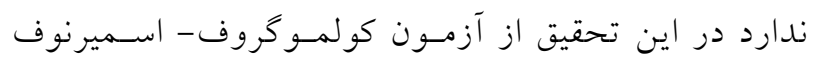

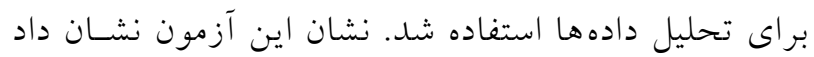

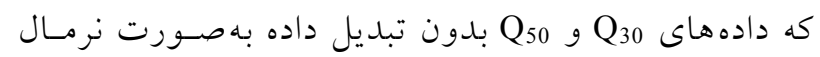

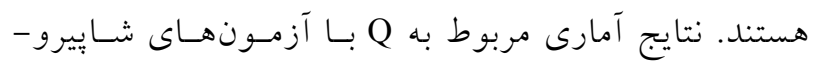
ويلك و كولمـو كروف- اسـميرنوف قبـل و بعسد از تبـديل

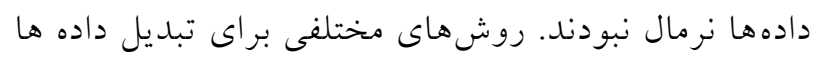

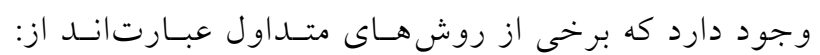

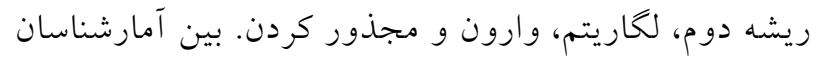

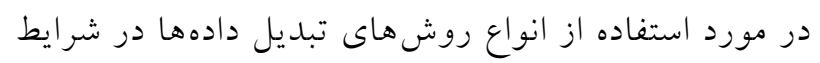

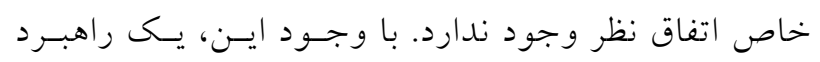

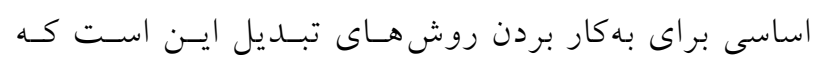

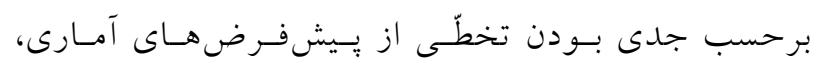

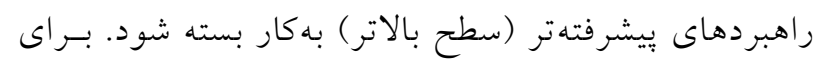

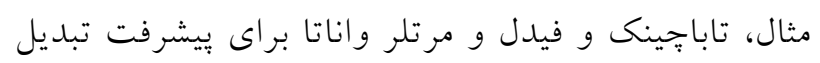
دادهها از ريشه دوم (براى اصلاح تخطّى متوسط)، لكاريتم

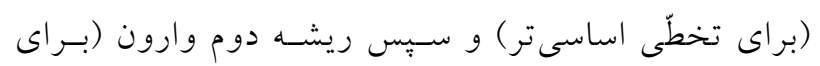

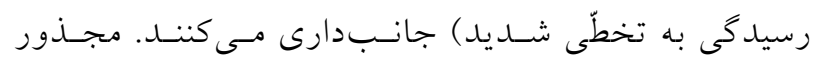
كردن يكى متغير در رابطه دو متغيـرى غيرخطّى مسى توانسد

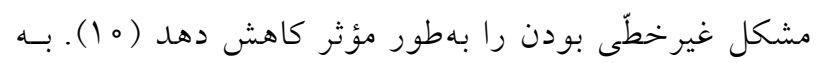

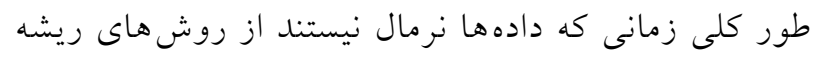

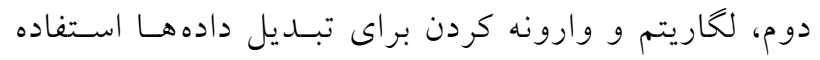

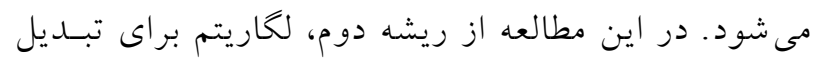
دادهها استفاده شد (م) (1).

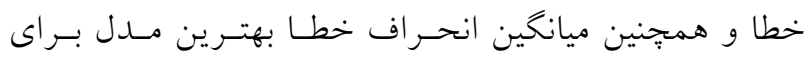

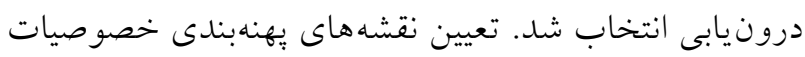

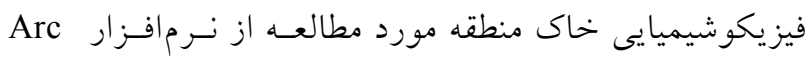

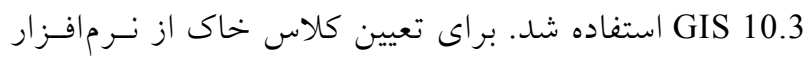

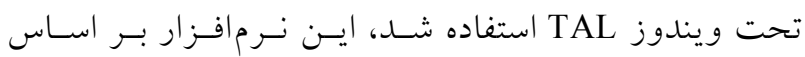
جنــدين سيستم طبقـهنـــى شـامل سيستمهــاى USDA،

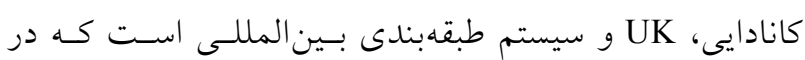
تحقيق حاضر از سيستم UDSA استفاده شد.

نتايج و بحث

نتايج محاسبه فرسايش با استفاده از روش سـازمان حفاظــت محيط زيست آمريكا

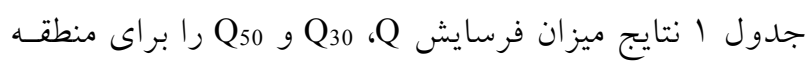

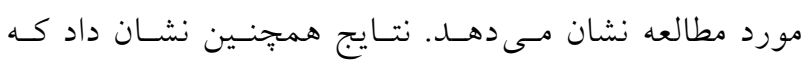

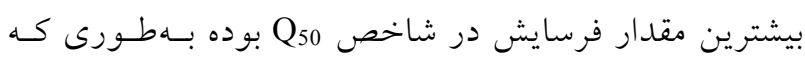
كمترين و بيشترين ميزان فرسايش در اين شاخص به ترتيـبـ

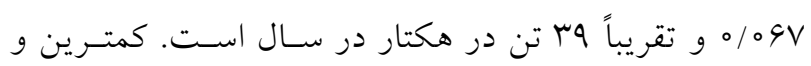

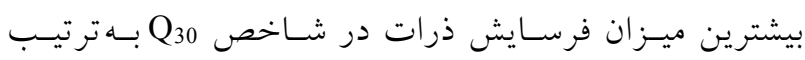

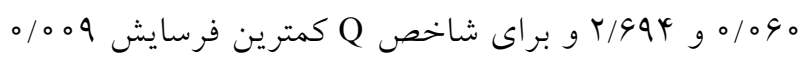

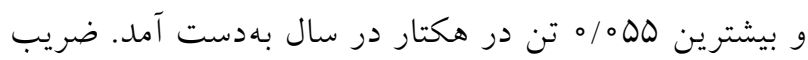

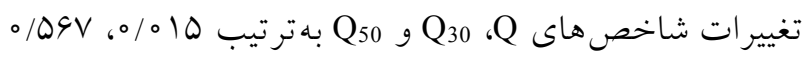

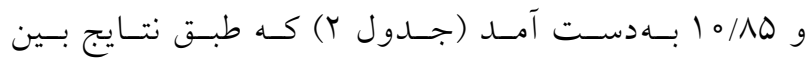

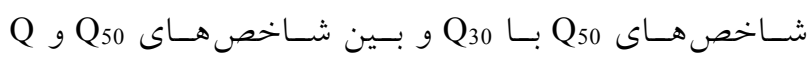
همبستخى مثبت و معنادار در سطح يكى درصد وجود دارد. با هـاي توجه به اينكه ميزان Q در اين تحقيـق مــنظر اسـت منطقـه. مورد مطالعه ما بر اساس اين بارامتر در وضعيت هشدار قرار

$$
\text { مى گيرد. }
$$

نتايج آمارى و نرمال بودن دادههاى فرسايش

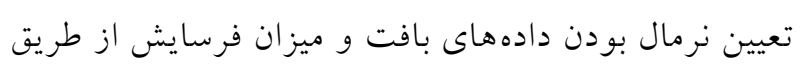

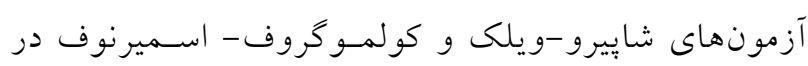

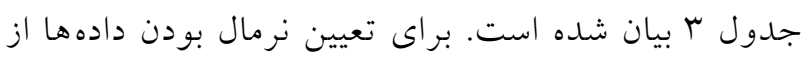


جدول ا. ميزان هدررفت خاك براى شاخصهاى Q, Q30 و Q50 منطقه مورد مطالعه

\begin{tabular}{|c|c|c|c|c|c|c|c|}
\hline Q30 & Q50 & Q & نمونه & Q30 & Q50 & Q & نمونه \\
\hline O/AYI & $19 / 4 T$ & $\circ / \circ \Delta \Delta$ & TS & $0 / r q \mu$ & T/TVQ & $0 / 0 T_{1}$ & 1 \\
\hline$|/ \mu V|$ & $T M / F Y$ & \% & TV & $0 / 490$ & & r/01r & r \\
\hline O/GKY & TYNG & $\circ / \circ \Delta \circ$ & TA & 1/4 & $V / 9 \circ Y$ & $\circ / 0 Y_{0}$ & $r$ \\
\hline$r / 994$ & $r G / 0 V$ & \% & rq & $1 / 091$ & r/qTG & $\circ / 0 Y_{0}$ & q \\
\hline $1 / 14 q$ & Tr/Ar & ०/OrV & $\mu_{0}$ & ه ه & $-/ Q Y Q$ & $0 / 041$ & 0 \\
\hline$|/| \psi \mid$ & IV/AM & $\circ / 0 \Delta \circ$ & r & $0 / 494$ & l/4k。 & $0 / 041$ & 9 \\
\hline$|/ \Gamma \wedge|$ & $|V / Y|$ & $\circ / \circ \Delta \circ$ & Tr & $0 / 090$ & $0 / 09 V$ & $0 / 0 \circ 9$ & V \\
\hline $0 / 9 \mu \wedge$ & $0 / 9 \mu_{1}$ & ०/OrV & سM & $0 / 9 \mathrm{Vr}$ & $0 / D / 4$ & O/OYY & $\wedge$ \\
\hline o/9०r & T/TKY & \% & ry & $0 / 099$ & $\circ / N Q \Lambda$ & $0 / 041$ & 9 \\
\hline $1 / \Lambda_{0}$ & $1 V / 19$ & $\circ / \circ \Delta \Delta$ & ه & r|xir & $\circ M_{Y}$ & $\circ / 0 T_{0}$ & 10 \\
\hline $1 / 9 Y^{\circ}$ & $r Q / Q T$ & $\circ / \circ \Delta \Delta$ & ra & $\circ / \mu \circ \psi$ & $0 / 4 G Y$ & $0 / 014$ & 11 \\
\hline I/ArG & $r G / Y \wedge$ & $\circ / \circ \Delta \Delta$ & rV & $0 /$ cra & T/DHQ & O/OTI & Ir \\
\hline ס זسו & سת/N & $\circ / \circ \Delta \Delta$ & r & $1 / 01 \mu$ & $V / 999$ & $\circ / 0 Y_{0}$ & Ir \\
\hline $1 / \mu \psi_{0}$ & rYMN & $\circ / \circ \Delta \Delta$ & rq & T/FTH & $1 N / 90$ & $0 / 014$ & 14 \\
\hline -/A9D & $m$ & $\circ / \circ \Delta \Delta$ & $\psi_{0}$ & I/rNT & $1 \% / \Delta q$ &.$/ 040$ & 10 \\
\hline $0 / 949$ & $T Y / Y Q D$ & $\circ / \circ \Delta \Delta$ & 41 & - $9 \Delta \Delta$ & $M T / K$ &.$/ 040$ & 19 \\
\hline O/YIV & G/MIr & $\circ / \circ \Delta \Delta$ & pr & سז// & rQ/or & $0 / 040$ & IV \\
\hline olgra & TQ/GT & $\circ / \circ \Delta \Delta$ & r & I/KT & YN/OY & سז0\% & 11 \\
\hline $0 / 991$ & $r q / r q$ & $\circ / \circ \Delta \Delta$ & ky & $1 / T Y Q$ & r/Tו & .040 & 19 \\
\hline $0 / 491$ & $11 / 21$ & $\circ / \circ \Delta \Delta$ & id & $1 / 090$ & $r q / 4 r$ &.$/ 040$ & ro \\
\hline -/AVV & rN/०Q & $\circ / \circ \Delta \Delta$ & 49 & $1 / 011$ & $r_{0} / \mu Q$ & $0 / 040$ & rI \\
\hline OMYK & $9 / 10.9$ & $\circ / \circ \Delta \Delta$ & qV & - $/ \Delta{ }^{\prime} \Delta$ & $1 / 901$ & ०/०০० & rY \\
\hline $1 / 1 r$ & $1 / \mu q \varphi$ & $\circ / \circ \Delta \Delta$ & is & $0 / 994$ & $\| / N \Lambda$ & ०/ HV & r \\
\hline $0 / 119$ & $10 / 94$ & $\circ / \circ \Delta \Delta$ & 49 & I/KY。 & $10 / 40$ & ०/ HV & TY \\
\hline $1 / 090$ & 10/K & $\circ / \circ \Delta \Delta$ & Q. & ०/9VG & G/או & $\circ / \circ \Delta \Delta$ & ro \\
\hline
\end{tabular}


جدول r. توزيع فراوانى ميزان فرسايش ذرات Q، Q30،

\begin{tabular}{|c|c|c|c|}
\hline Q30 & Q50 & Q & يار امترها \\
\hline o/9Ar & $\mid Y / \Lambda \Lambda$ & $0 / 040$ & ميانگين \\
\hline$\circ / \circ \wedge \circ$ & 1/or。 & ०/०० & خطا ميانخين \\
\hline$\circ / 09 V$ & $10 / \wedge \Delta$ & $0 / 010$ & ضريب تغييرات \\
\hline OMYT & $11 \mathrm{~V} / \mathrm{A}$ & $0 / 001$ & واريانس \\
\hline $0 / 040$ & $0 / 09 \mathrm{~V}$ & $0 / 09$ & كمترين \\
\hline r/994 & rN/०G & $\circ / \circ \Delta \Delta$ & بيشترين \\
\hline
\end{tabular}

جدول r. تعيين نرمال بودن دادهها

\begin{tabular}{|c|c|c|c|c|c|c|c|}
\hline \multicolumn{3}{|c|}{ شابيرو - ويلك } & \multicolumn{3}{|c|}{ كولمو گروف - اسميرنوف } & \multirow{2}{*}{ 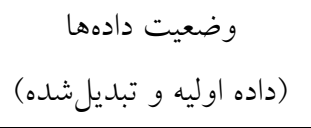 } & \multirow{2}{*}{ يار امترها } \\
\hline معنادارى & درجه آزادى & آمارى & 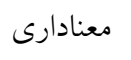 & درجه آزادى & آمارى & & \\
\hline$\% \circ 00$ & Q. & o/Arq & $\circ \% \circ$ & Q. & $0 / 1 \wedge 9$ & داده اوليه & \multirow{2}{*}{ Q } \\
\hline$\circ / 000$ & ఎ० & $\circ / \mathrm{VAl}$ & $\circ / 0 \circ$ & め. & $0 / Y Y_{0}$ & داده تبديل شده & \\
\hline ००सा & Q. & $0 / 949$ & $\circ / Y_{0}$ & D. & $0 / 090$ & داده اوليه & \multirow{2}{*}{ Q30 } \\
\hline$\circ / 9 V T$ & D. & $0 / 991$ & $\circ / Y_{0}$ & D. & $\circ / 0 \vee q$ & داده تبديل شده & \\
\hline$\circ / Y_{0}$ & め० & $0 / 944$ & $\circ / Y_{\circ}$ & Q. & $0 / 099$ & داده اوليه & \multirow{2}{*}{ Q50 } \\
\hline$\circ / \circ \Delta \circ$ & Q० &.$/ 9 \Delta Y^{Y}$ & $\circ / Y_{0}$ & D० & $0 / 101$ & داده تبديل شده & \\
\hline
\end{tabular}

براى شاخص Qد30 مدل نمايى با توجـه يـا بار امترهـاى ضـريب

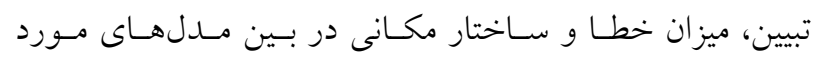

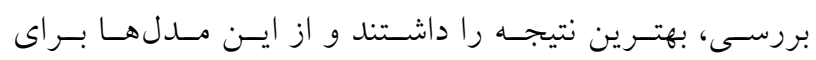
درونيابى با استفاده از روش هاى زمسين آمـارى اسـتفاده شـــ. نتايج ضريب تبيين نشان داد كه اين ميزان در مدل كوسى براى

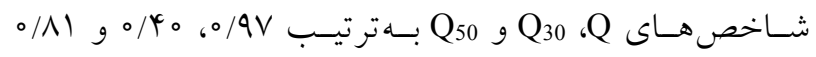
بوده كه براى شاخصهاى Q و Q Qـن مقـدار بسـيار بـالا و قابل قبول بوده اما در مورد شاخص Q30 با وجود مقدار يـايين

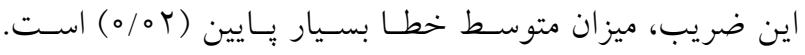

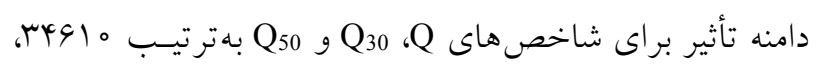

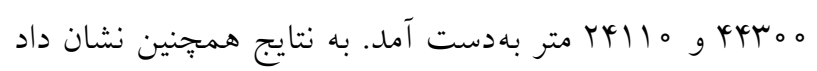
كه ساختاريذيرى (موقعيت مكانى) دادهها براى شـاخص هـاى

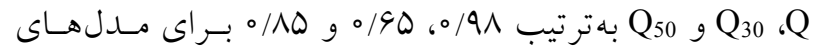
كوسى، نمايى، كوسى بود. ميزان شـاخص (C+Co

\section{نتايج ساختاريذيرى و واريوگرام دادهها} با استفاده از نرمافزار GS متغيرهاى مدل، اثر قطعهاى (C) (C)، حد

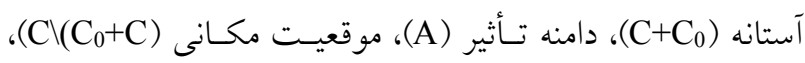

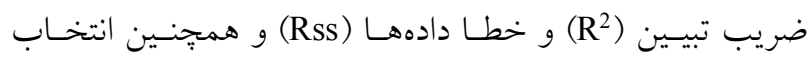
بهترين مدل بـراى واريـو گر ام متغيرهـاى مـورد مطالعـهـ از بـين مدلهاى كروى، نمايى، خطى و گوسى صورت گرفت. جـدول

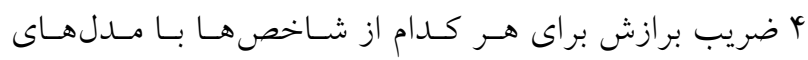

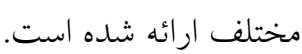

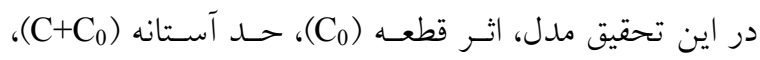

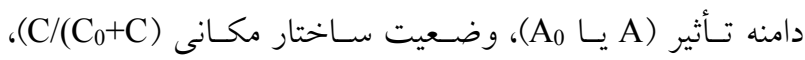
ضريب تبيين (Rss) و ميزان خطا (Rss)، براى بِرامترهـاى مسورد مطالعه با استفاده از نرمافزار GS و بار مدلهاى كـروى، نمـايى، خطى و كوسى مورد تجزيه و تحليل قرار گرفته شد. با توجه به نتايج بهدست آمده، براى شاخص هاى Q و Q50 مــل كوسلى و و 
جدول f. جدول نتايج واريوكرامها و ساختاريذيرى

\begin{tabular}{|c|c|c|c|c|c|c|c|}
\hline RSS & $\mathrm{R}^{2}$ & $\mathrm{C} / \mathrm{C}+\mathrm{C} 0$ & دامنه تأثير (A) & حد آستانه (C+C0) & اثر قطعهاى (C0) & 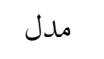 & متغير \\
\hline$" 9 / 99$ & $0 / 19$ & 1 & 01100 & $\circ$ & $\circ$ & كروى & \multirow{4}{*}{$\mathrm{Q}$} \\
\hline$" V / 90$ & $\circ / \wedge V$ & 1 & 01100 & $\circ$ & 。 & نمايى & \\
\hline$" Q / \wedge$ 。 & $0 / 90$ & 1 & roto. & 。 & 。 & خطى & \\
\hline " & $\circ / 9 V$ & $\circ / 91$ & rrsi. & 。 & 。 & كوسى & \\
\hline$\% \% r$ & $\circ / 4 \circ$ & $\circ / 0$ & 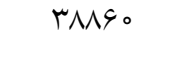 &.$/ 40$ & $0 / T T$ & كروى & \multirow{4}{*}{ Q30 } \\
\hline $0 / 0 Y$ & $\circ / \Psi_{0}$ & $0 / 90$ & ketoo & $0 / 90$ & $0 / T r$ & نمايى & \\
\hline$\circ / 10$ & $\circ / \mu q$ & $\circ / 4 q$ & $19 \mathrm{TV}$ & $\circ / T V$ & ת & خطى & \\
\hline $0 \% r$ & 0,49 & $\circ / 0^{\circ}$ & TrYOO & $\circ / 0 \circ$ & $\circ / T \Delta$ & 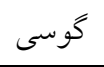 & \\
\hline$V^{r} v$ & $\circ / 09$ & $\circ / 19$ & TYOI。 & $r 91 / \pi$ & $199 / 91$ & 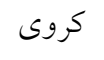 & \multirow{4}{*}{ Q50 } \\
\hline$V T \circ D$ & $0 / 91$ & $\circ / \wedge \Delta$ & rQSi。 & TNI/D & $\varphi \circ / \mu$ & نمايى & \\
\hline$V T \wedge D$ & $\circ / N Q$ & $\circ \mathrm{NA}$ & $19 T V 0$ & $M N / V$ & rN/FV & خطى & \\
\hline k194 & $\circ / \wedge)$ & $\circ / 1 \Delta$ & FYll。 & 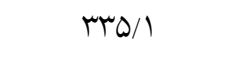 & GY/。 & كوسى & \\
\hline
\end{tabular}

درونيابى مورد نظر انجام شد. معيارهاى مختلفى بـراى مقايسـه

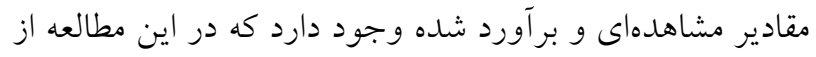

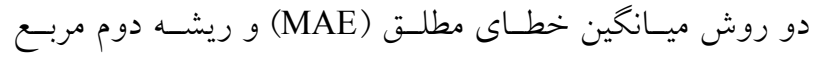
ميانخين خطا (RMSE) استفاده شد.

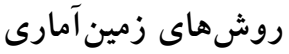

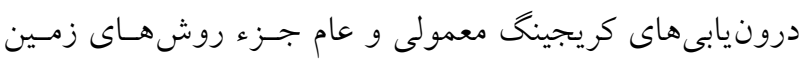

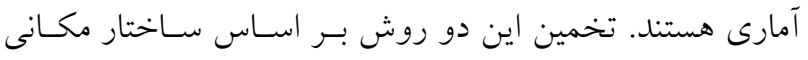

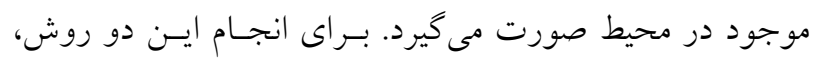

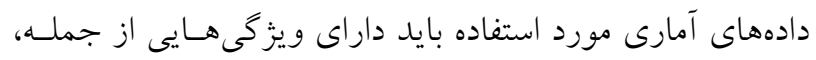

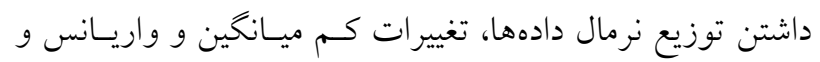

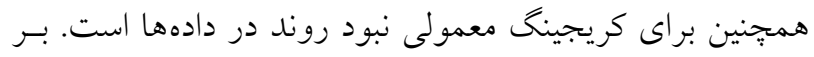

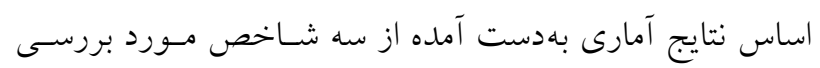

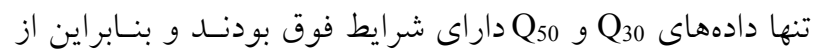

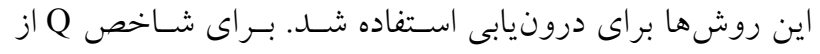
روش هاى غير زمين آمارى استفاده شد. آزمون همسانكردى نيـز

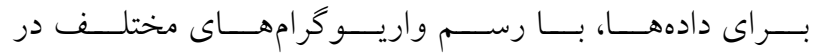

از QD درصد نشاندهنده ساختاريذيرى قـوى، ميـزان شـاخص بين QD تا VD درصد نشاندهنده ساختاريذيرى متوسط و بيش از VD درصد، نشاندهنده سـاختاريذيرى ضعيف اسـت (19).

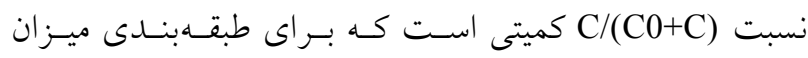
وابستخى مكانى متغيرها بهكار مىرود. اخر نسـبت كفتـه شــده

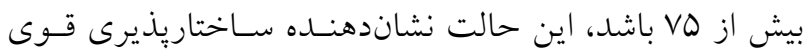

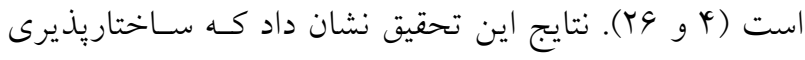
تمام شاخص ها بهجز Q30 بسيار قوى بوده و بنابر اين با توجسه

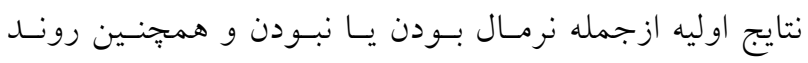

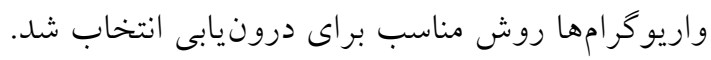

\section{مقايسه و ارزيابى روشهاى درونيابى}

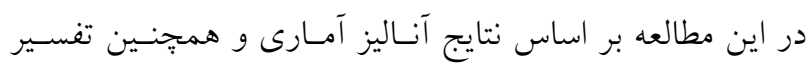

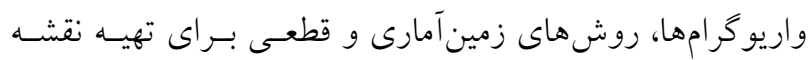

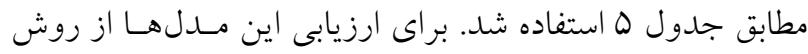
اعتبارسنجى متقاطع استفاده شد. در اين روش براى هـر يـــ از از

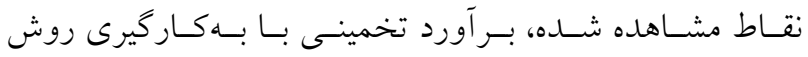


جدول ه. مقايسه روشهاى درونيابى براى شاخصهاى Q، Q30 و Q50

\begin{tabular}{|c|c|c|c|c|}
\hline \multicolumn{2}{|c|}{ يار امترهاى آمارى } & \multirow{2}{*}{ متغير } & \multirow{2}{*}{ مدل درونيابى } & \multirow{2}{*}{ نوع درونيابى } \\
\hline MAE & RMSE & & & \\
\hline$r / r \Delta V$ & $9 / 019$ & Q50 & \multirow[b]{2}{*}{ كريجينخ معمولى } & \multirow{4}{*}{$\begin{array}{c}3 \\
3 \\
3 \\
y \\
\frac{3}{3} \\
\frac{3}{3} \\
\frac{3}{3}\end{array}$} \\
\hline o/4ke & $\circ / \Delta Q V$ & Q30 & & \\
\hline T/YヘS & $9 / 10$ & Q50 & \multirow[b]{2}{*}{ كريجينگ عام } & \\
\hline o/lrt & $\circ / \Delta \circ \Delta$ & Q30 & & \\
\hline $0 / 0094$ & $0 / 0094$ & Q & \multirow{3}{*}{ فاصله وزنى معكوس } & \multirow{9}{*}{$\begin{array}{c}3 \\
3 \\
3 \\
y \\
3 \\
3\end{array}$} \\
\hline.$/ 1$ ro & $\circ / \Delta Y \circ$ & Q30 & & \\
\hline $1 / 19 V$ & $r / 94$ & Q50 & & \\
\hline O/OOH & $0 / 009$ & Q & \multirow{3}{*}{ تابع شعاعى } & \\
\hline.$/ 010$ & O/QT & Q30 & & \\
\hline T/DSV & $0 / 99$ & Q50 & & \\
\hline$\circ / 0 \circ Y$ & $\circ / \circ \circ \wedge \varphi$ & Q & \multirow{3}{*}{ جندجملهاى محلى } & \\
\hline $0 / 799$ &.$/ 019$ & Q30 & & \\
\hline$T / \mid Q \Lambda$ & $\Delta / \Gamma \wedge$ & Q50 & & \\
\hline
\end{tabular}

وزنى معكوس براى بارامتر Q50 با مقادير كمتـرين ميـزان خطـا 1/19 r/94 و ميانخين خطاى مطلق (RMSE) بهترين عملكرد را بين مدلهاى مورد بررسى داشـت. در رابطـه. با شاخص Q مدل جندجملهاى محلى بـا كمتـرين ميـزان خطــا

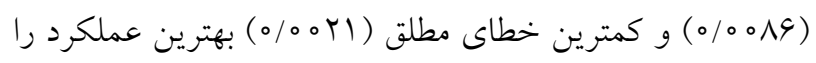
داشت (جدول ه). بهطور خلاصه نتايج ارزيابى مدلها بر اساس كمترين ميزان خطا بهشرح زير است: ميزان Q LPI>RBF>IDW و و ميز ان Q. نقشههاى ميزان فرسايش براى اسـاس بهتـرين روش درونيـابى

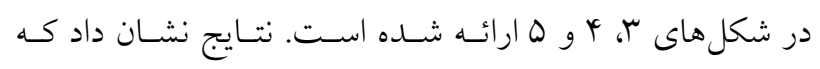

جهتهاى گوناگون انجام شد. يكسان بودن واريو گرامهـا نشـان دهنده همسانگرد بودن توزيع دادهها در منطقه است. نتايج نشان داد كه كريجينخ عام براى شاخص Q30 با كمترين ميـزان خطـا و ميانخين خطاى مطلق (RMSE)

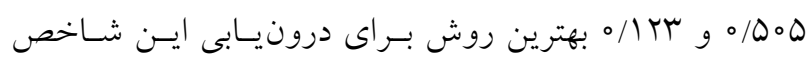

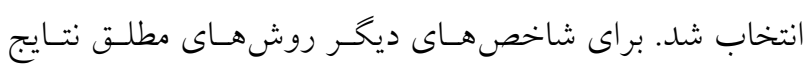
بهترى در مقايسه با روشهاى زمين آمارى نشان دادند. روش هاى قطعى يا معين از روشهاى غير زمين آمارى، روشهاى فاصله وزنى معكـوس، لهـئ

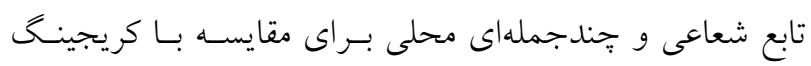

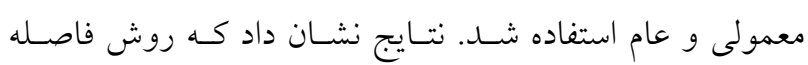




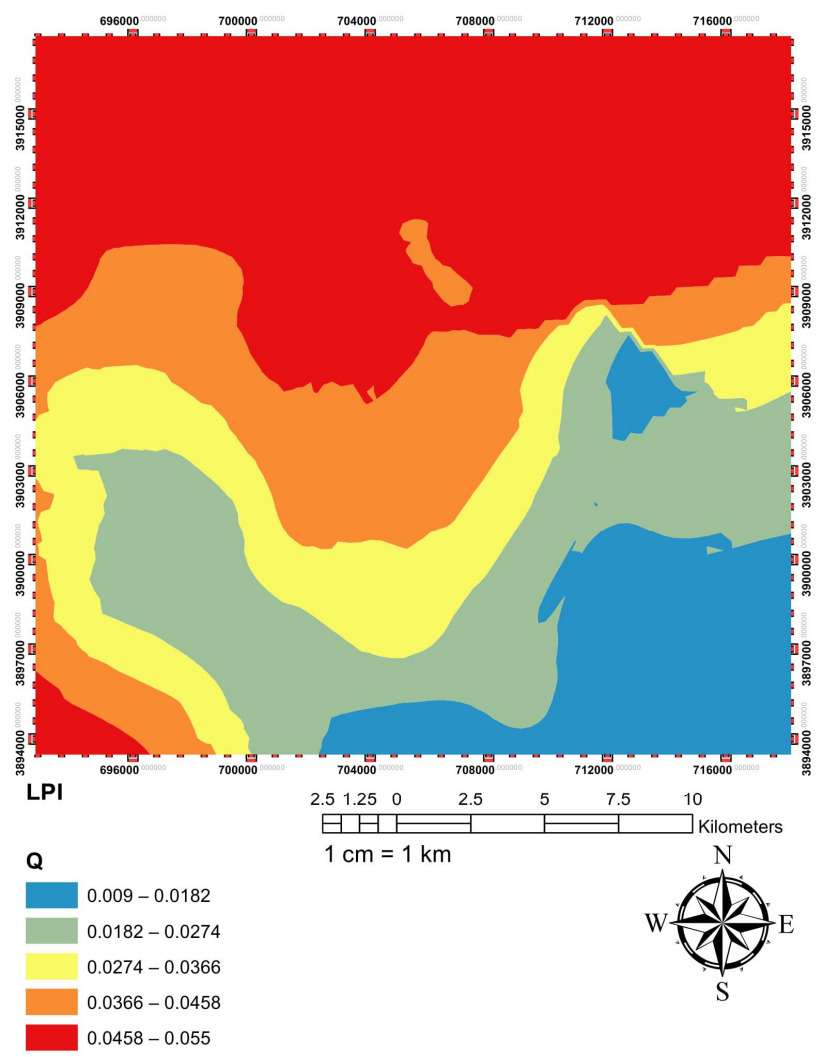

شكل r. نقشه بر اكنش ميزان شاخص Q با روش LPI (رنكى در نسخه الكترونيكى)

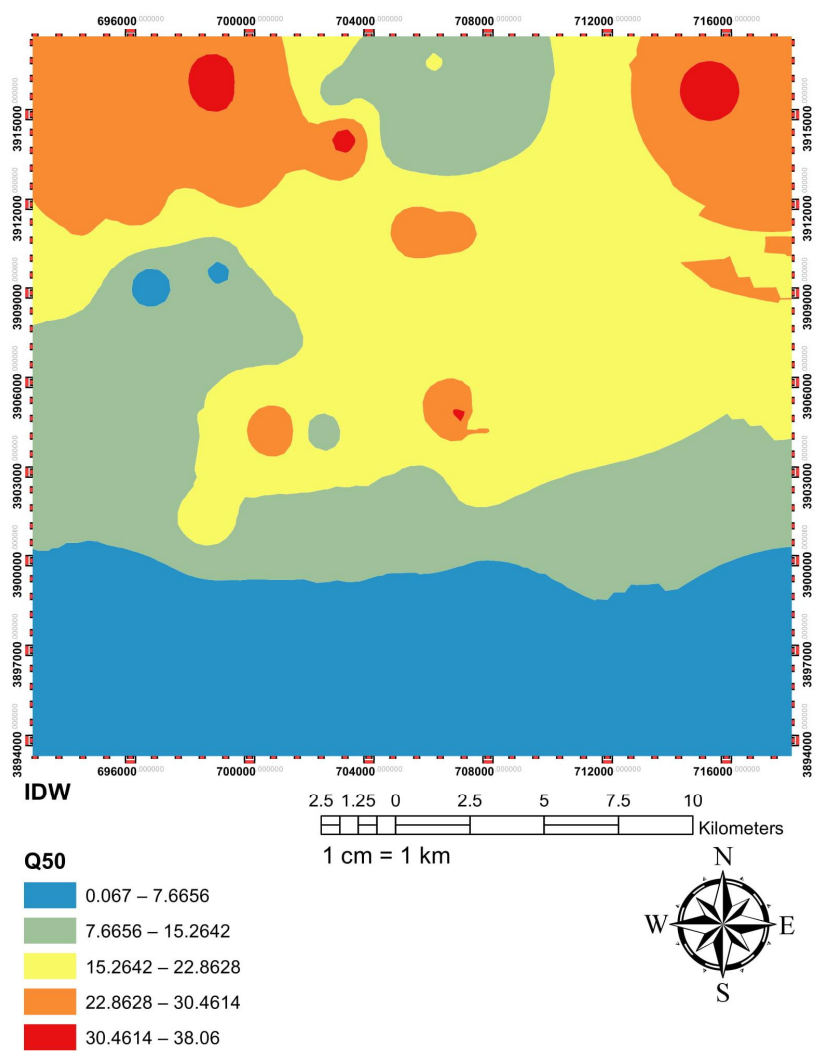

شكل f. نقشه براكنش ميزان شاخص Q50 با روش IDW (رنكى در نسخه الكترونيكى) 


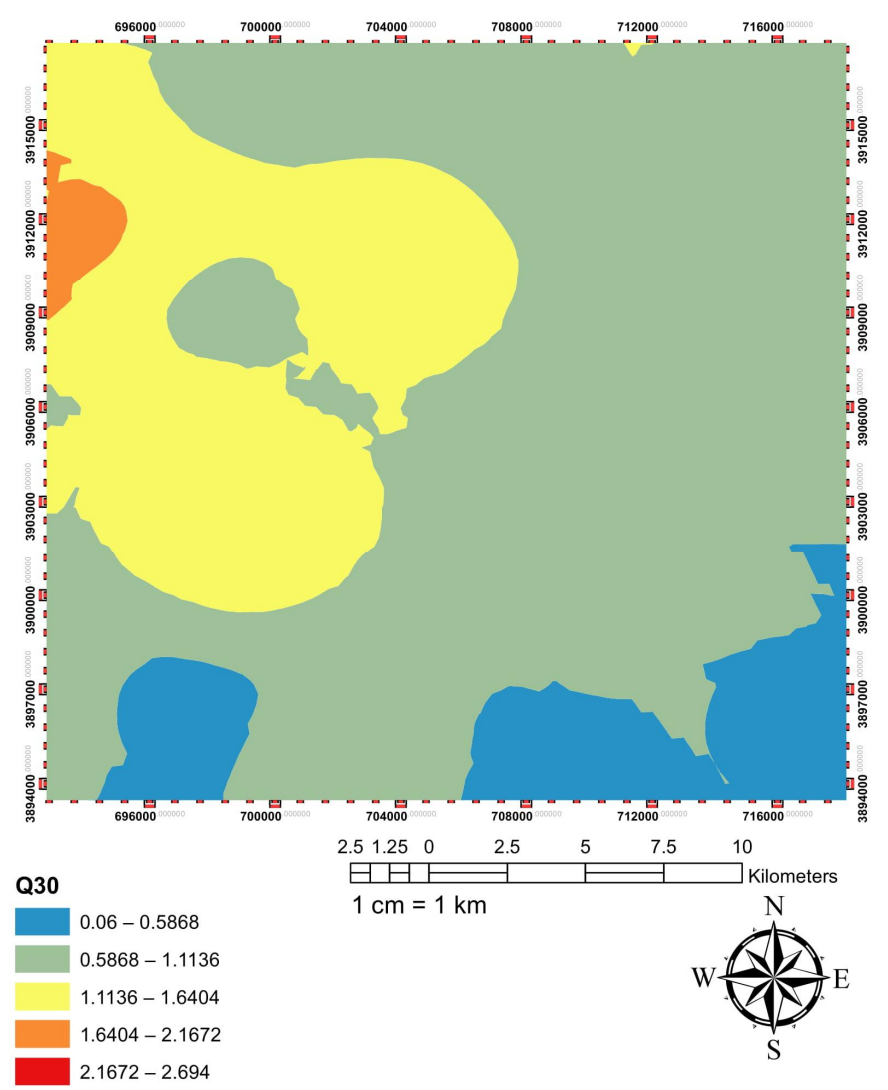

شكل ه. نقشه بِر اكنث ميزان شاخص Q30 با روش K (رنكى در نسخه الكترونيكى)

دادند. نتايج اين تحقيق نشان داد كـه روش كريجينــ بـا مـــل كروى، ساختار فضايى مناسبتر و مقادير خطسـاى كمتـرى دارد.

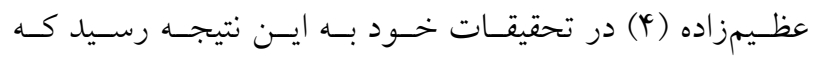

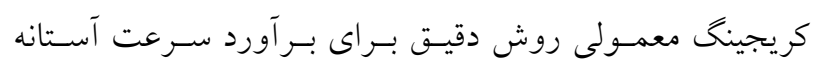

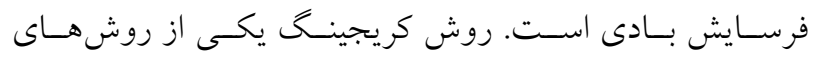

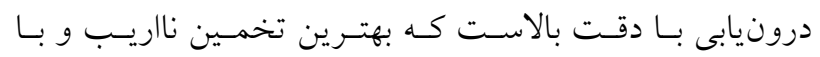
كمترين مقدار واريانس را فراهم مىنمايســ (†). محاسـبه مقــدار

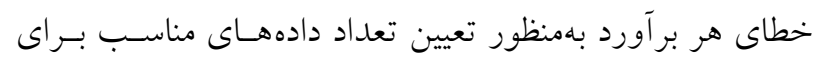

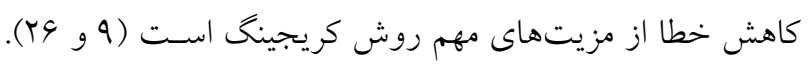

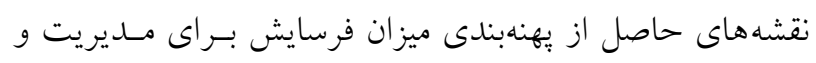
كنترل هدررفت خاك توسط سازمانهاى محسيط زيستـ، منـابع

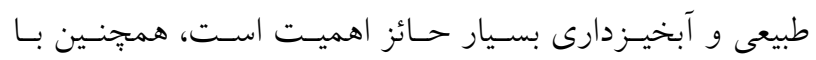

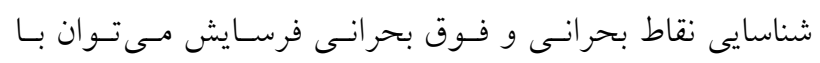

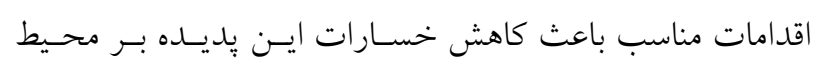

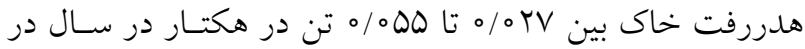

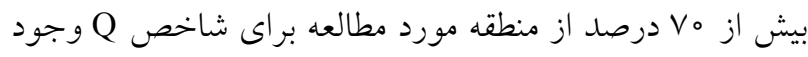

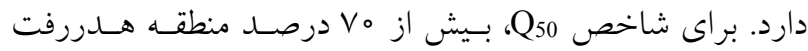

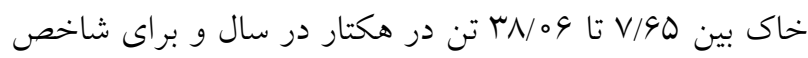
Q بيش از ه9 9 درصد هدررفت خاك بين هكتار در سال فرسايش وجود دارد. دليل هدررفت بالاى خـاك

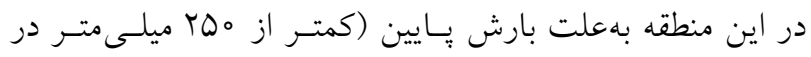

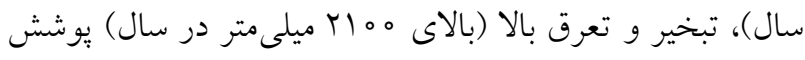

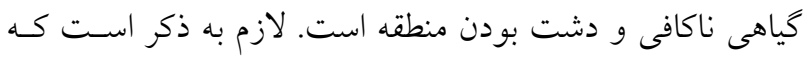

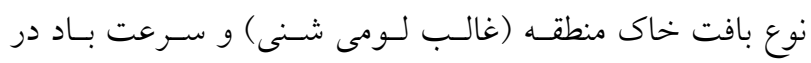

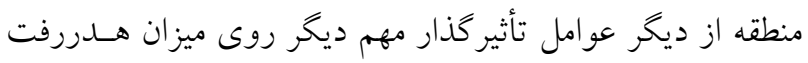

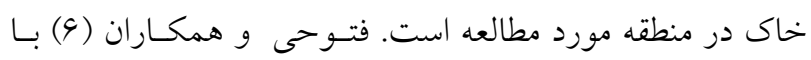

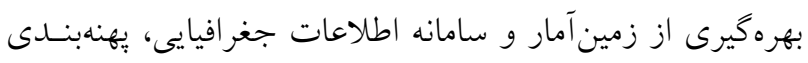

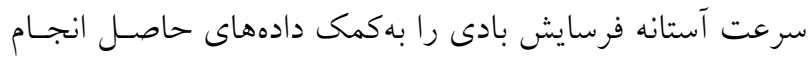




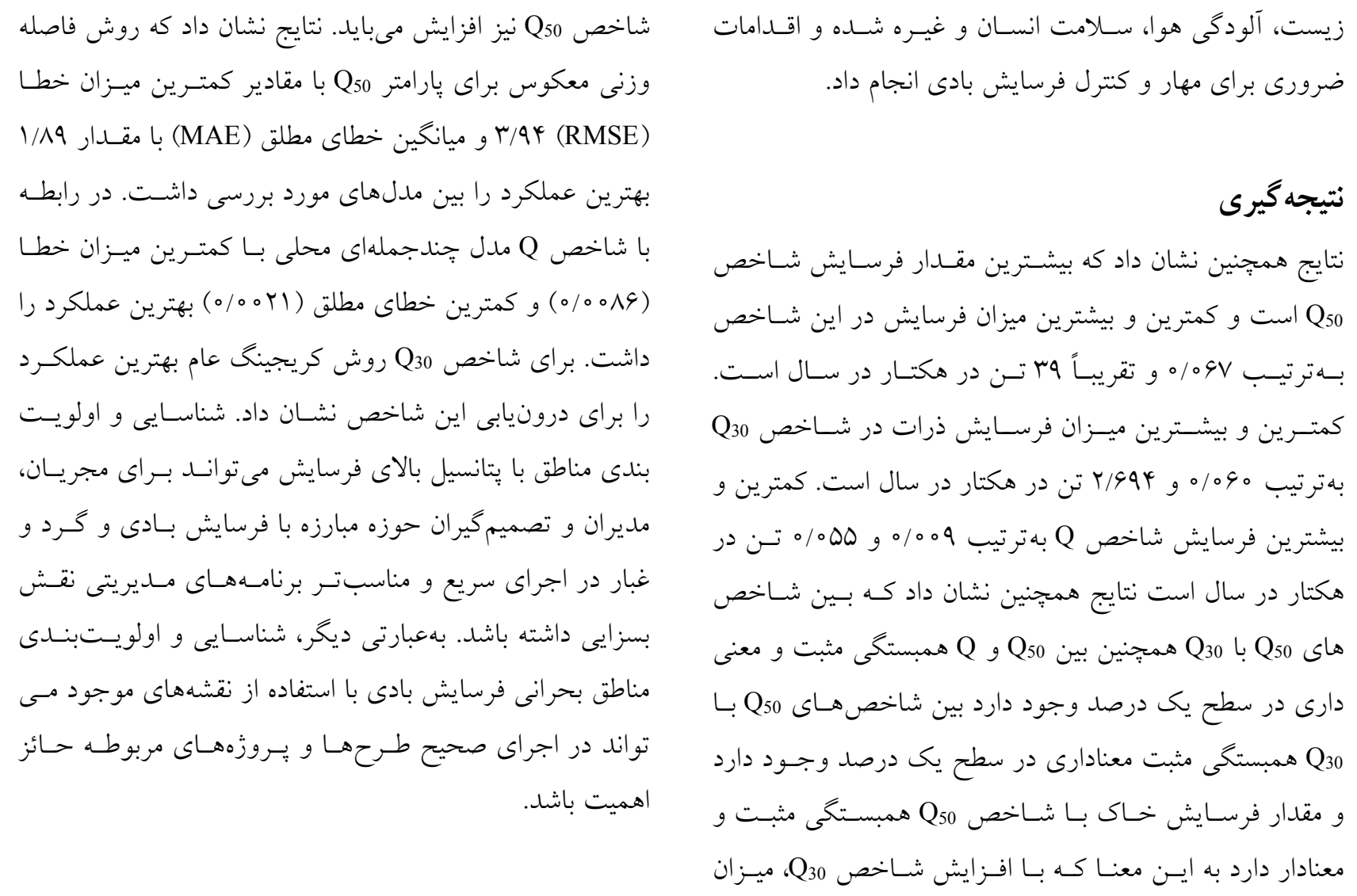

1. Akhtesasi, M. and A. Zare Chahuki. 2016. Evaluation of prediction of IRIFR1 wind erosion and comparison with direct measurement of wind erosion using wind erosion measuring machine (WEmeter) in Segzi plain, Isfahan. Iranian Rangeland Research Journal 23(2): 264-225 .

2. Akhtesasi, M. and H. Ahmadi. 1997. Qualitative and quantitative study of wind erosion and sediment estimation in Ardakan-Yazd plain. Iranian Journal of Natural Resources 12(1): 50-59.

3. Amin, P. and H. R. Azimzadeh. 2015. The effect of desert pavement on soil wind erodibility and wind erosion threshold velocity (Case Study: Ebrahimabad basin of Mehriz (Yazd). Quantitative Geomorphological Research 4(2): 90-104.

4. Azimzadeh, H. R., M. R. Akhtesasi, J. Mohammadi and H. G. Refahi. 2005. Application of Kriging geostatistics in estimation of desert pavement percentage and wind erosion threshold speed, 1st National Conference on Wind Erosion, Iran.

5. Black, C. A. 1965. Methods of Soil Analysis, American Society of Agronomy Madison, WI.

6. Fotouhi Firouzabad, F., H. R. Azimzadeh and A. S. Talebi. 2014. Comparative evaluation of interpolation methods in estimating the erodibility index of the global soil loss equation (Case study: part of Yazd-Ardakan plain). Watershed Research 103: 21-13.

7. Hashemi, Z., M. Javadi and A. S. Miri. 2010. Evaluation of wind erosion and its sedimentation potential using IRFR model in Zakak region of Sistan and Baluchestan province. Journal of Natural Resources Science and Technology 6(3): 41-48.

8. Isaaks, E. and R. Srivastava.1989. Applied Geostatistics, New York Oxford University Press.

9. Jianbing, W., A. Boucher and T. Zhang. 2008. A SGeMS code for pattern simulation of continuous and categorical variables: FILTERSIM. Computers and Geosciences 4(12): 1863 -1876.

10. Karimi, R. 2015. Easy Guide to Statistical Analysis with SPSS, Hemgham Publication, Hengham.

11. Klute, A. 1988. Methods of Soil Analysis 2d ed., pt. 1; Physical and Mineralogical Methods, Soil Science, USA.

12. Mihanprast, S. 2015. Evaluation of wind erosion severity using IRIFR method and determination of severity of 
harvest, transportation and sedimentation zones (study area, south of Semnan). Master Thesis, Semnan University, Iran.

13. Nazari Samani, A. S., A. Ehsani, A. Gliwari and M. Abdolshahnejad. 2015. Comparison of results of RWEQ and IRIFR models in determining land management impact on wind erosion. Journal of Desert Management 6: 53-39.

14. Pi, H. 2017. Evaluation of two empirical wind erosion models in arid and semi-arid regions of China and the USA. Environmental Modelling \& Software 91: 28-46.

15. Refahi, H. A. 2006. Wind erosion and its control. University of Tehran Publications, Tehran.

16. Saremi Naeini, M. A., A. Jahromi Farmers, M. A. Akhtesasi and A. S. Mohammadian Behbahani. 2007. Zoning of wind erosion threshold velocity values using geostatistics (Case Study: Yazd City Area). 10th Iranian Soil Science Congress, Karaj, Iran.

17. Shakarian, N., Gh. Zahatabyan and B. Shakarian. 2010. The Impact of dust and microbes and their pollutions on human health. Second National Conference on Wind Erosion, Yazd, Iran.

18. Tang, J. 2011. Influence of biological aggregating agents associated with microbial population on soil aggregate stability. Applied Soil Ecology 47(3): 153-159.

19. Torabi, H., N. Dwatgar and Sh. Qasemi. 2016. Investigation of spatial variation and zoning of some physical and chemical properties of surface soil and their influence on agricultural management in South Tehran. Journal of Soil Research and Soil and Water Sciences 30(2): 12-25.

20. Vaezi, A. R., H. A. Bahrami, S. H. R. Sadeghi and M. H. Mahdian. 2010. Spatial Variability of Soil Erodibility Factor (K) of the USLE in North West of Iran. Journal Of Agricultural Science And Technology (JAST) 12: 252241.

21. Xie, Y. 2011. Spatial distribution of soil heavy metal pollution estimated by different interpolation methods: Accuracy and uncertainty analysis. Chemosphere 82(3): 468-476.

22. Xuan, J., G. Liu and K. Du. 2000. Dust emission inventory in Northern China. Atmospheric Environment 34: $4565-$ 4570.

23. Xuan, J., I. N. Sokolik, J. Hao, F. Guo, H. Mao and G. J. Yang. 2004. Identification and characterization of sources of atmospheric mineral dust in East Asia. Atmospheric Environment 38: 6239-6252.

24. Xuan, J. 1999. Dust emission factors for environment of Northern China. Atmospheric Environment 33: $1767-1776$.

25. Zare Chahouki, M. A., M. Zare Ernani, A. Zare Chahouki and L. Khalasi Ahvazi. 2010. Application of spatial statistical methods in predictive models of plant species habitat. Journal of Arid Biom Scientific and Research 1(1): 13-23.

26. Zare Chahuki, M., M. Abbasi and H. Azarniwand. 2015. Spatial distribution map of some soil properties using geostatistical methods (Case study: Middle Talegan rangelands). Range Journal 12: 56-67. 


\title{
Comparison of Interpolation Methods for the Mapping of Wind Erosion using the USEPA Model
}

\author{
E. Moradi and D. Namdar Khojasteh ${ }^{1^{*}}$
}

(Received: December 07-2019; Accepted: July 05-2020)

\begin{abstract}
Wind erosion is one of the environmental problems worldwide, particularly in arid and semi-arid areas of Iran. Different methods and models have been proposed to measure and monitor wind erosion in the recent years. One of the accurate models for measuring $f$ wind erosion is the USEPA model. The purpose of this study was to evaluate the quantification of wind erosion with the USEPA model and the comparison of different interpolation methods for drowsing highprecision soil erosion mapping. For this purpose, 50 samples from 0-30 depth were taken from the study area. Based on the analysis of the physical properties of the soil, including the distribution of the primary and secondary particle sizes, climatic parameters such as evaporation and transpiration, rainfall, wind speed and also, the vegetation and topography characteristics of the area, the erosion rates of $\mathrm{Q}, \mathrm{Q}_{30}$ and $\mathrm{Q}_{50}$ were measured. Interpolation methods including general kriging, IDW, LPI and RBF were compared. The results showed that the highest erosion emission rate of $\mathrm{Q}_{50} \mathrm{was} 39$ ton $\mathrm{ha}^{-1}$. The highest and lowest erosion rates for the $\mathrm{Q}_{30}$ index were 0.060 and 2.694 ton ha $\mathrm{h}^{-1}$, respectively; for the $\mathrm{Q}$ index, the highest and lowest erosion rates were 0.009 and 0.055 ton ha ${ }^{-1}$, respectively. The results also showed that the IDW method for the $\mathrm{Q}_{50}$ index with the minimum error rate (RMSE) values of 3.94 and the mean absolute error (MAE) with the valueof 1.89 had the best performance among the studied models. The LPI model Q had the best performance with the lowest error (0.0086) and absolute absolute error (0.0021).
\end{abstract}

Keywords: Spatial Distribution, Kriging, Interpolation, Wind Erosion

1. Department of Soil Science, Faculty of Agriculture, Shahed University.

Corresponding author, Email: d.namdarkhojasteh@shahed.ac.ir 